\title{
Timing metabolism in cartilage and bone: links between circadian clocks and tissue homeostasis
}

\author{
Cátia F Gonçalves and Qing-Jun Meng \\ Wellcome Centre for Cell Matrix Research, Division of Cell Matrix Biology and Regenerative Medicine, School of Biological Sciences, Faculty of Biology, \\ Medicine \& Health, Manchester Academic Health Science Centre, University of Manchester, Manchester, UK
}

Correspondence should be addressed to Q-J Meng: qing-jun.meng@manchester.ac.uk

\begin{abstract}
The circadian system in mammals is responsible for the temporal coordination of multiple physiological and behavioural processes that are necessary for homeostasis. In the skeleton, it has long been known that metabolic functions of chondrocytes, osteoblasts and osteoclasts exhibit intrinsic circadian rhythms. In addition, results from animal models reveal a close connection between the disruption of circadian rhythms and skeletal disorders such as rheumatoid arthritis, osteoarthritis and osteoporosis. In this review, we summarise the latest insights into the genetic and biochemical mechanisms linking cartilage and bone physiology to the circadian clock system. We also discuss how this knowledge can be utilised to improve human health.
\end{abstract}

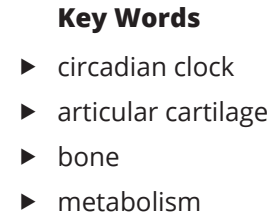

Journal of Endocrinology (2019) 243, R29-R46

\section{Introduction}

Circadian (from the Latin circa diem, meaning 'about a day') rhythms in behaviour and physiology are a hallmark of life on earth. The 24-h environmental cycles generated by the planet's rotation around its axis have been wired into the molecular machinery of cells from all domains of life (Bell-Pedersen et al. 2005). This endogenous timekeeping mechanism, known as circadian clock, allows organisms to anticipate the periodic fluctuations brought on by the 24-h solar cycle, aligning biological functions with external changes (Pittendrigh 1993).

Skeletal homeostasis is an intrinsically dynamic process whose complexity not only derives from the number of molecules involved and their multifaceted interactions, but also from their precise spatial and temporal control. Remarkably, physiological functions such as longitudinal bone growth, bone remodelling, chondrocyte metabolism and cartilage matrix turnover exhibit 24-h rhythms, being controlled by the peripheral circadian clocks present in most of the cell types in cartilage and bone (Dudek \& Meng 2014, Yang \& Meng 2016). Alterations in the circadian rhythm of skeletal biology are associated with the development of various disorders, including osteoarthritis (OA), rheumatoid arthritis (RA) and osteoporosis (OP) (Kawai \& Rosen 2010, Gibbs \& Ray 2013, Berenbaum \& Meng 2016).

In this review, we summarise the current understanding of the links between the circadian clock and skeletal metabolism. Specifically, we discuss how the circadian clock is implicated in the regulation of several facets of cellular metabolism that are essential for bone and cartilage homeostasis. We also elaborate on the utilisation of animal models to dissect the roles of circadian pathways in skeletal metabolism and pathophysiology of diseases. Finally, we provide an overview of the latest advances in chronotherapy and other translational aspects of circadian biology and discuss how these can be 
used to improve existing therapies and develop new ones for musculoskeletal conditions.

\section{Circadian rhythms in mammals: a coordinated network of hierarchical oscillators}

The mammalian circadian system comprises a multitude of oscillators organised in a hierarchy (Fig. 1) (Honma 2018). The central clock, located in the suprachiasmatic nucleus (SCN) of the anterior hypothalamus, is directly entrained by photic information transmitted to the SCN via the retinohypothalamic tract (Gooley et al. 2001, Hattar et al. 2002, Panda et al. 2002a). Nonphotic stimuli such as behavioural arousal, melatonin and serotonergic activation are also capable of resetting the central clock; these cues are usually conveyed to the SCN via the geniculohypothalamic tract and the dorsal and median raphe nucleus (Challet \& Pévet 2003, Dibner et al. 2010). The SCN clock regulates daily oscillations in mammalian behaviour and physiology, including locomotor activity, sleep-wake cycles, blood pressure, body temperature, pineal melatonin secretion and adrenal corticosterone release (Moore \& Eichler 1972, Moore \& Klein 1974, Eastman et al. 1984, Kramer et al. 2001, Scheer et al. 2005, Buijs et al. 2014). Additionally, the central clock acts as a pacemaker that relays crucial timing information to autonomous peripheral oscillators through neural and humoral outputs, such as parasympathetic and sympathetic innervation and glucocorticoid hormones (Balsalobre et al. 2000, Albrecht 2012, Buijs et al. 2014).

Circadian rhythms in the expression of genes and proteins have been reported in cells and tissues from across all organ systems. Genome-wide transcriptome studies have demonstrated that between 3 and $16 \%$ of the transcripts detected in peripheral tissues are rhythmically expressed (Panda et al. 2002b, Storch et al. 2002, Zvonic et al. 2006, Gossan et al. 2013, Dudek et al. 2016, 2017, Yang et al. 2017). In fact, a systems-level analysis of the murine transcriptome indicated that more than half of the genes encoding proteins are rhythmic in at least one tissue (Zhang et al. 2014). Notably, there is little overlap between the genes under circadian control in each tissue, demonstrating that the temporal orchestration of cellular metabolism is tissue specific (Mohawk et al. 2012, Buhr \& Takahashi 2013, Zhang et al. 2014). This is reflected in the broad range of molecular pathways that are coordinated by the circadian clock, ranging from photoreception in the retina to xenobiotic detoxification in the liver and kidneys (Gachon et al. 2006, Storch et al. 2007). These tissue-specific gene expression patterns are presumably related to the gradual emergence of circadian rhythms during development through mechanisms that are deeply interlocked with cellular differentiation processes (Reppert \& Schwartz 1986, Davis \& Gorski 1988, Jud \& Albrecht 2006, Yagita et al. 2010, Umemura et al. 2017).

Peripheral clocks rely on a unique combination of timing cues to fine-tune cellular functions. Although the central clock does not drive peripheral oscillators,

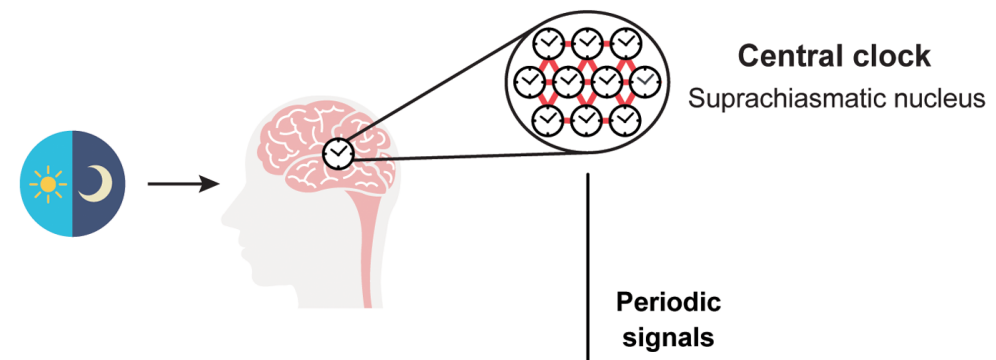

$\Sigma=\theta$
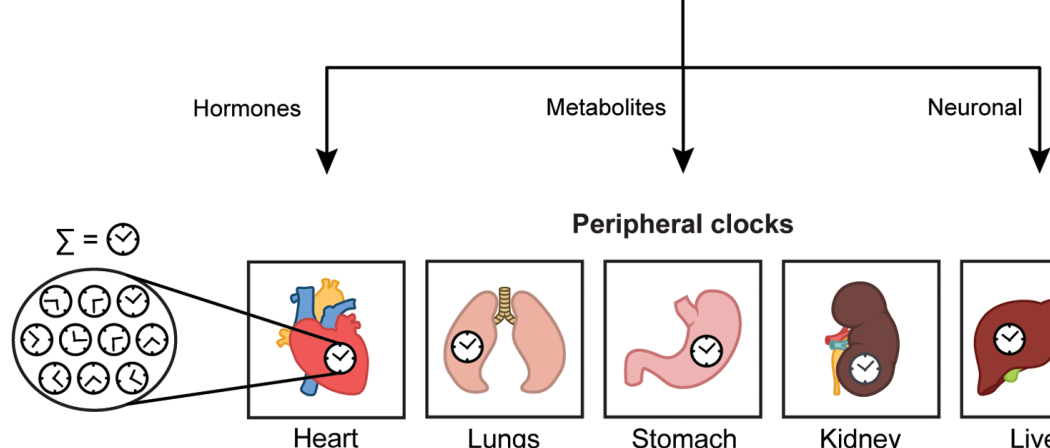

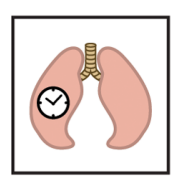

Lungs
Peripheral clocks

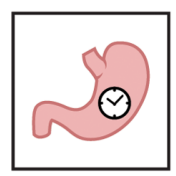

Stomach

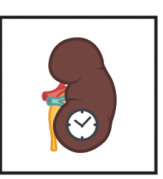

Kidney

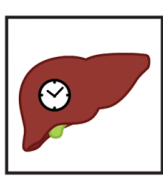

Liver
Figure 1

Hierarchical organisation of the mammalian circadian system. The central clock located in the suprachiasmatic nucleus ( $\mathrm{SCN}$ ) of the hypothalamus receives light/dark information from the retina through the retinohypothalamic track. Intercellular coupling between neurons ensures synchronised circadian rhythms of the SCN (top right). Periodic signals (e.g. humoral and neuronal) released from the central clock convey timing information to entrain circadian oscillators located in peripheral tissues. For most peripheral tissues, there is no coupling or weak coupling between cells. However, robust tissue-level oscillations can be achieved due to stochastic population entrainment. Peripheral circadian clocks modulate tissue-specific rhythmic expression of genes involved in metabolism, thermoregulation and many other physiological outcomes. https://joe.bioscientifica.com https://doi.org/10.1530/JOE-19-0256
(C) 2019 Society for Endocrinology Published by Bioscientifica Ltd. Printed in Great Britain 
information originating in the SCN is essential for the synchronisation of phases between cells of the same tissue and establishing a stable phase interval between different tissues (Yoo et al. 2004, Guo et al. 2006). Nonetheless, the maintenance of systemic synchrony in mammals seems to be far more complex than initially suggested (Kowalska \& Brown 2007, Husse et al. 2015). This is evidenced by parabiosis studies between intact and SCN-lesioned mice demonstrating that nonneural cues are sufficient to sustain circadian rhythms in the liver and kidneys, but not in the heart, spleen and muscle (Guo et al. 2005). In addition, the loss of synchrony in peripheral tissues caused by deletion of BMAL1 in the SCN was distinctively rescued by light/dark cycles and restricted feeding depending on the peripheral oscillator (Izumo et al. 2014). Nonetheless, more studies are necessary to fully comprehend how peripheral clocks interact with each other and with the SCN and how this regulation is achieved.

\section{The molecular circadian clock}

On a molecular level (Fig. 2), the circadian clock consists of intricate self-regulatory transcription-translation

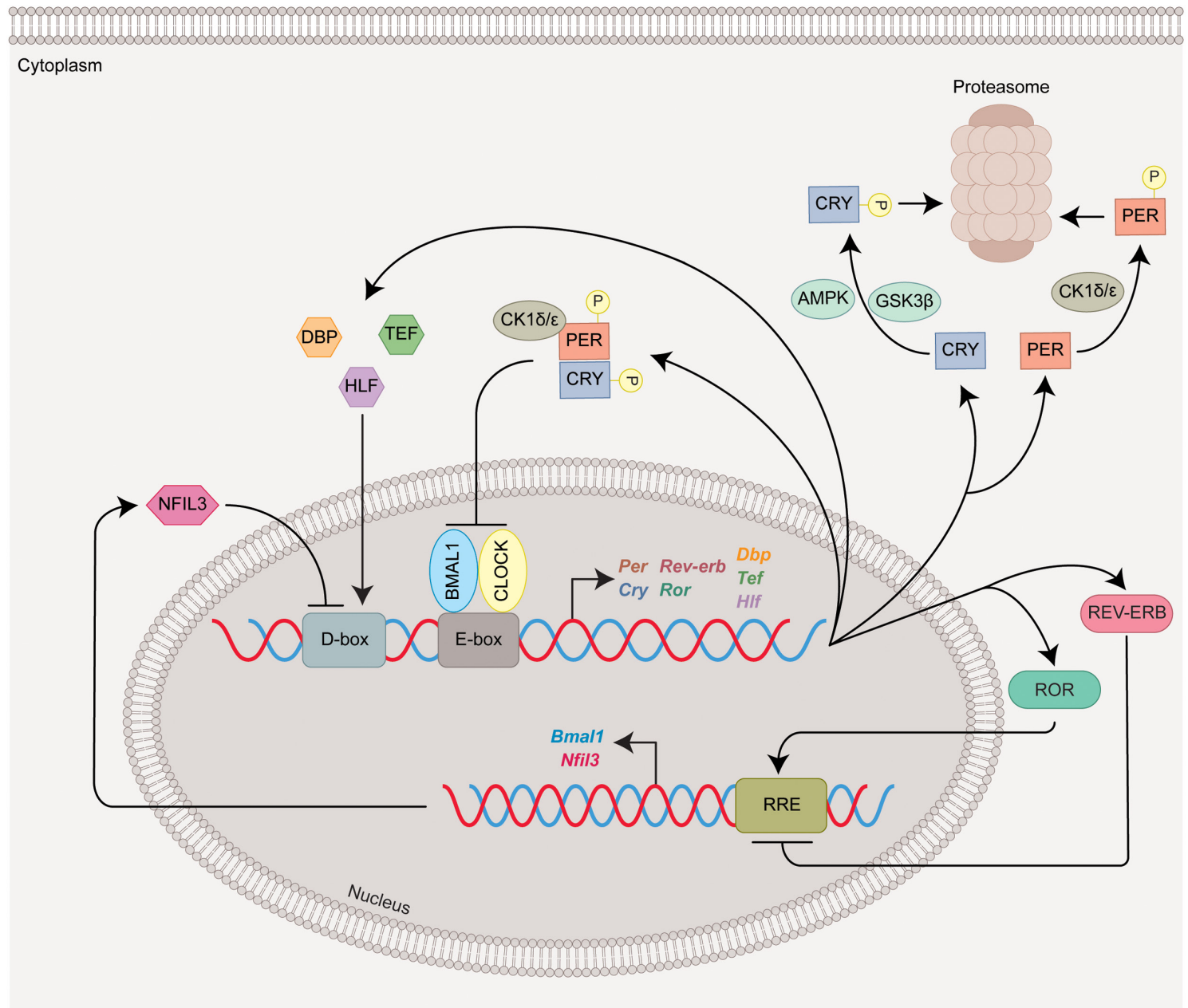

Figure 2

Molecular mechanisms of the mammalian circadian clock. The circadian transcriptional-translational feedback loop comprises CLOCK-BMAL1 heterodimers that bind to E-box elements in the promoter region of clock-controlled genes, namely Per1/2, Cry $1 / 2$, Rev-erba/b, Rora/c, Dbp, Tef and HIf. In the cytoplasm, PER1/2 and CRY1/2 form a complex and are phosphorylated by CK1E/ $\delta$. The resulting complex represses the transcriptional activity of CLOCK-BMAL1. Cytoplasmic degradation of PERs and CRYs is mediated by CK $1 E / \delta, A M P K$ and GSK3 $\beta$, respectively. REV-ERBs and RORs drive another feedback loop that participates in the transcriptional control of Bmal1. A third feedback loop involves the transcriptional activators DBP, TEF and HLF and the repressor NFIL3 that bind rhythmically to D-box elements. AMPK, 5' adenosine monophosphate-activated protein kinase; BMAL1, brain-muscle-arntlike protein 1; CLOCK, circadian locomotor output cycle kaput; CRY1/2, cryptochrome 1/2; CK1 $\varepsilon / \delta$, casein kinase $1 \varepsilon / \delta$; DBP, D-box-binding protein; GSK3, glycogen synthase kinase 3 $\beta$; HLF, hepatic leukaemia factor; NFLI3, nuclear factor interleukin 3 regulated; P, phosphate residue, PER1/2, period 1/2; $\mathrm{ROR} \alpha / \gamma$, retinoic acid receptor-related orphan nuclear receptor $\alpha / \gamma ; \mathrm{RRE}$, retinoic acid response elements; TEF, thyrotroph embryonic factor. 
feedback loops whose interactions govern the rhythmic expression of clock-controlled genes (Reppert \& Weaver 2002, Mohawk et al. 2012). The positive arm of the main feedback loop is formed by the transcriptional factor CLOCK (circadian locomotor output cycles kaput) and its heterodimeric partner BMAL1 (brain and muscle Arntlike protein-1) (King et al. 1997, Gekakis et al. 1998, Lowrey \& Takahashi 2011). The CLOCK-BMAL1 complex binds to E-box elements in the promoter region of target genes, including Period (Per1, Per2 and Per3) and Cryptochrome (Cry1 and Cry2), which are members of the negative arm of the feedback loop (Gekakis et al. 1998, Kume et al. 1999, Shearman et al. 2000). In the cytosol, PER and CRY interact with each other to form a complex and are phosphorylated by serine/threonine casein

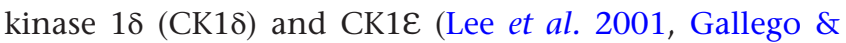
Virshup 2007). This PER-CRY repressor complex is then translocated into the cell nucleus where it represses its own transcription by interacting with CLOCK-BMAL1 (Lee et al. 2001, Lowrey \& Takahashi 2011). As repression progresses, specific E3 ubiquitin ligase complexes ubiquitinate PER and CRY proteins, marking them for degradation by the proteasome (Gallego \& Virshup 2007, Preußner \& Heyd 2016). Once the turnover of the repressor complex reaches a certain threshold, negative feedback is relieved and transcription of Per and Cry starts anew, initiating a new circadian cycle.

In addition to Per and Cry, the CLOCK-BMAL1 complex also activates the transcription of NR1D1 (nuclear receptor subfamily 1 , group $\mathrm{D}$, member 1 ) and NR1D2 (nuclear receptor subfamily 1, group D, member 2) that encode the nuclear receptors REV-ERB $\alpha$ and REV$E R B \beta$, respectively. Rhythmic expression of REV-ERB $\alpha$ leads to the repression of Bmal1 thereby inducing a rhythm in these genes that is in antiphase with Per expression (Preitner et al. 2002). Retinoic acid-related orphan receptor (ROR) proteins (ROR $\alpha$ and ROR $\gamma$ ) compete with REV-ERBs for their shared DNA-binding elements (Preitner et al. 2002, Sato et al. 2004, Zhang et al. 2015), which results in the transcriptional activation of Bmal1 by ROR $\alpha$ and its repression by REV-ERB $\alpha$ (Solt et al. 2011). In this way, the REV-ERB-ROR feedback loop interconnects the positive and negative arms of the main feedback loop.

A third transcriptional loop driven by CLOCKBMAL1 involves the proline and acidic amino acid-rich basic leucine zipper (PAR-bZIP) factors D-box-binding protein (DBP), thyrotroph embryonic factor (TEF) and hepatic leukaemia factor (HLF). These proteins interact with the repressor NFIL3 (nuclear factor interleukin-3 regulated), which is driven by the REV-ERB/ROR loop, at sites containing D boxes (Mitsui et al. 2001, Gachon et al. 2004). Together, these integrated feedback loops generate intricate transcription-translation circuits with various phases of expression that vary according to the combination of cis elements in the promoters and enhancers of target genes (Ueda et al. 2005).

\section{Articular cartilage}

Articular cartilage (AC) is present in the articular surfaces of diarthrodial joints. AC is a specialised connective tissue that consists of a dense extracellular matrix (ECM) comprising protein fibres (collagen and elastic fibres) and ground substance (proteoglycans, glycosaminoglycans and glycoproteins), surrounding a sparse population of chondrocytes, the only cell type in this tissue (Mescher 2016). The regenerative potential of AC is inherently limited, meaning that once damaged this tissue is very difficult to repair (Iwamoto et al. 2013). Articular chondrocytes live in a challenging physicochemical environment: no innervation, no blood or lymphatic vessels, high osmotic pressure, acidic $\mathrm{pH}$ and low oxygen levels ( $\mathrm{Ng}$ et al. 2017). As these cells rarely divide, cartilage homeostasis depends on the fine balance between chondrocyte anabolism and catabolism and their temporal regulation (Archer \& Francis-West 2003). Disruption of chondrocyte metabolism has been linked to musculoskeletal disorders such OA and RA, which are characterised by a shift towards chondrocyte catabolism and progressive ECM degeneration (Goldring $\&$ Marcu 2009).

\section{Evidence of circadian rhythms in articular cartilage}

Circadian variations in cartilage were first described by studying the mitotic activity of chondrocytes in the epiphyseal growth plate of mice and rats, with the highest mitotic index occurring in the early morning (Simmons 1962, 1964a, Kember \& Walker 1971, Stevenson et al. 1990). Several studies have also reported that the incorporation of $\left[{ }^{35} \mathrm{~S}\right]$ sulphate, $\left[{ }^{3} \mathrm{H}\right]$ proline, $\left[{ }^{3} \mathrm{H}\right]$ galactose, $\left[{ }^{14} \mathrm{C}\right]$ proline $/\left[{ }^{14} \mathrm{C}\right]$ glycine or $\left[{ }^{3} \mathrm{H}\right]$ thymidine increased during the light phase in rat and mouse growth plates (Simmons 1964a,b, Walker \& Kember 1972, Raugstad et al. 1979, Russell et al. 1983, Igarashi et al. 2013). In patients with knee OA and RA, the levels of cartilage oligomeric matrix protein (COMP) in serum presented a circadian variation (Andersson et al. 2006). Day/night variations could also be observed 
for other biomolecules related to cartilage metabolism in OA patients, namely aggrecan, type II collagen, hyaluronic acid, keratan sulphate and transforming growth factor- $\beta$ (TGF- $\beta$ ) (Kong et al. 2006). Nonetheless, the lack of a normal control group in these studies limits the interpretation of these findings.

In the last decade or so, bioluminescence imagining techniques have greatly improved our knowledge of the molecular clocks driving circadian rhythms in various tissues. These techniques make use of reporter mice harbouring the firefly luciferase gene fused in-frame with the 3 ' end of the Per2 gene (PER2::Luc), which permits real-time monitoring of circadian rhythms (Yoo et al. 2004). In 2013, Okubo and colleagues proved that the articular and epiphyseal cartilage of femoral bone from PER2::Luc mice have strong circadian oscillations in ex vivo culture for several months (Okubo et al. 2013). Similar approaches have revealed circadian rhythms in explant cultures of cartilage isolated from the xiphoid process and the femoral head of PER2::Luc mice (Gossan et al. 2013, Dudek et al. 2016). Circadian rhythms can also be observed in human primary and immortalised cell lines of chondrocytes transduced with lentiviral clock gene reporters (Gossan et al. 2013, Dudek et al. 2016).

Global transcriptome analyses have confirmed the rhythmic expression of core clock genes in cartilage isolated from the xiphoid process and femoral head of mice and from the ribs and femoral head of rats (Gossan et al. 2013, Honda et al. 2013, Dudek et al. 2016). By collecting samples from mice and rats constantly kept in darkness it has been possible to identify global circadian patterns of gene expression (Gossan et al. 2013, Honda et al. 2013). In both organisms, approximately $4 \%$ of the expressed genes showed statistically significant circadian rhythms (Gossan et al. 2013, Honda et al. 2013). Interestingly, many of these rhythmic genes are involved in cellular processes that are crucial for the maintenance of cartilage homeostasis, such as ECM structural components (e.g. aggrecan and collagen) and remodelling enzymes (e.g. Adamts1, Adamts 4 and Adamts9), calcium-dependent metalloproteinases (e.g. Mmp14), inhibitors of metalloproteinases (e.g. Timp3 and Timp4) and growth factors (e.g. Tgfa, Tgfbr3 and Egf) (Gossan et al. 2013, Honda et al. 2013, Yang \& Meng 2016). Most importantly, these studies point towards a circadian regulation of cartilage metabolism with a time-of-day-dependent segregation of anabolic and catabolic pathways (Gossan et al. 2013, Honda et al. 2013).

\section{Links between dysregulation of circadian rhythms and articular cartilage homeostasis}

In recent years, evidence has emerged that disruption of circadian rhythms by environmental or genetic factors may contribute to the development of skeletal disorders. In aged mice, the amplitude of circadian oscillations is reduced approximately $40 \%$ in comparison to young mice; and it is known that age is one of the main risk factors for the development of OA (Hugle et al. 2012, Gossan et al. 2013). This reduction in the amplitude of circadian oscillations could impact on the regulation of downstream genes involved in cartilage metabolism. It has also been reported that long-term environmental disruption of light/dark cycles that mimics many years of rotating shift work or chronic jet lag promotes the development of an OA-like phenotype in murine knee cartilage (Kc et al. 2015).

In mice, targeted deletion of Bmal1 in chondrocytes (Col2a1-Bmal1--) abolished the time-dependent expression of many rhythmic genes and led to early-onset cartilage degeneration (Table 1) (Dudek et al. 2016). Most importantly, gene expression studies in Col2a1-Bmal1-/mice demonstrated that BMAL1 is essential to maintain the balance between anabolic and catabolic factors in chondrocytes (Dudek et al. 2016). In the absence of this core clock component there is a dysregulation of the TGF- $\beta$ and NAFTC2 signalling pathways (Dudek et al. 2016). TGF- $\beta$ plays a crucial role not only in cartilage development during embryogenesis but also in the maintenance of its functional and structural integrity throughout adult life (Finnson et al. 2012, Wang et al. 2014). In aged murine chondrocytes this cytokine was associated with a diminished repair capacity (Scharstuhl et al. 2002, Blaney Davidson et al. 2005, Fortier \& Miller 2006). Furthermore, dysregulation of the TGF- $\beta$ signalling pathway has been correlated with an increased expression of MMP13 in human osteoarthritic cartilage (Blaney Davidson et al. 2009). The NFAT (nuclear factor of activated $T$ cells) family of transcription factors also participates in several biological processes essential for cartilage health (Ranger et al. 2000, Greenblatt et al. 2013). NFATc2 has been shown to regulate the differentiation of adult mesenchymal stem cells into cartilage in mice (Ranger et al. 2000). In Nfatc2-/mice, ectopic endochondral ossification is initiated at three months of age, and at a later stage extensive cartilage degradation may occur (Ranger et al. 2000, Wang et al. 2009). Loss of NFATc2 causes a metabolic imbalance in chondrocytes that is characterised by the overexpression of inflammatory (e.g. $I l 1 b$ and $I l 6$ ) and catabolic pathways 
Table 1 Summary of the phenotypes observed in articular cartilage from mouse models deficient in core circadian clock components.

\begin{tabular}{|c|c|}
\hline Mouse strain & Phenotype \\
\hline Bmal1-/- & Smaller body size \\
\hline Col2a1-Bmal1-/- & $\begin{array}{l}\text { Age-related progressive knee } \\
\text { cartilage degeneration } \\
\text { Cell death and extracellular } \\
\text { matrix loss }\end{array}$ \\
\hline Clock ${ }^{\Delta 19}$ & $\begin{array}{l}\text { Progressive proteoglycan } \\
\text { loss in knee cartilage }\end{array}$ \\
\hline
\end{tabular}

\begin{tabular}{l} 
Molecular changes \\
\hline Decreased expression of Alp, Ihh and Co/10a1 in rib \\
growth plate \\
Decreased expression of Acan, Col2a1, Ctgf, Id3, \\
Nfatc2/NFATc2, Nr1d1, Per2, p-SMAD1/5, p-SMAD2, \\
Serpine1 and Sox9/SOX9 in hip cartilage \\
Increased expression of I/1b, I/6/IL6, Mcp1 and \\
nuclear P65 in knee cartilage \\
Decreased expression of cytoplasmic P65 and IкB in \\
knee cartilage
\end{tabular}

\section{References \\ (Takarada et al. 2012) \\ (Dudek et al. 2016)}

(Yuan et al. 2019) knee cartilage

(e.g. Mmp13, Adamts5 and Timp1) and a decrease in anabolic signalling (e.g. Sox9, Acan and Col2a1) (Wang et al. 2009). Remarkably, expression of NFATc1 in lesioned cartilage from OA patients is downregulated in comparison with paired macroscopically normal samples (Greenblatt et al. 2013). Cartilage-specific ablation of NFATc1 in Nfatc2-/- mice induced the spontaneous development of an OA-like phenotype that recapitulates all the main features of human $\mathrm{OA}$, that is, prevalence of matrix catabolism, osteophyte formation and subchondral bone changes (Greenblatt et al. 2013).

Mice carrying a mutation in Clock $\left(\right.$ Clock $\left.^{\Delta 19}\right)$ presented accelerated cartilage degeneration in comparison to the wild type (Table 1) (Yuan et al. 2019). An increase in the expression of genes encoding proinflammatory cytokines such as IL-1 $\beta$ and IL-6 was also observed (Yuan et al. 2019). Interestingly, dysfunctional CLOCK decreased acetylation of NF- $\kappa \mathrm{B}$ at Lys310 and increased its phosphorylation at Ser276 thereby promoting its translocation into the nucleus (Yuan et al. 2019). Future studies should investigate whether reduced NF- $\mathrm{B}$ acetylation in a wildtype mouse recapitulates the same phenotype.

Analysis of gene expression patterns in human cartilage revealed that circadian rhythm pathways were among the most disrupted in OA patients (Akagi et al. 2017, Soul et al. 2018). Several studies have also demonstrated that expression of BMAL1/BMAL1 is significantly reduced in human osteoarthritic cartilage (Dudek et al. 2016, Snelling et al. 2016, Yang et al. 2016a, Akagi et al. 2017). Knockdown of BMAL1 in human chondrocytes altered TGF- $\beta$ signalling and was associated with increased expression of catabolic factors (e.g. MMP1, MMP3, MMP13 and ADAMTS5) (Snelling et al. 2016, Yang et al. 2016a, Akagi et al. 2017, Khurana et al. 2019).

Disruption of rhythmic genes other than the core clock components has also been associated with abnormal cartilage metabolism. Autophagy, a cellular mechanism that allows the rapid elimination of abnormal proteins and/or organelles, is involved in the maintenance of AC cartilage by modulating chondrocyte function and survival (Bohensky et al. 2007, 2009). In OA, a decrease in chondrocyte autophagy was accompanied by an increase in cell death and matrix degradation (Caramés et al. 2012). Thus, apoptosis inhibition has been proposed as a therapeutic intervention for OA (Kim \& Blanco 2007). Interestingly, expression of Xiap (X-linked inhibitor of apoptosis) was shown to be rhythmic in wild-type mouse xiphoid cartilage (Gossan et al. 2013). XIAP inhibits at least two members of the caspase family of cell death proteases, caspase- 3 and caspase-7, and has shown antiapoptotic activity in chondrocytes (Scott et al. 2005, Böhm et al. 2010). Therefore, loss of Xiap rhythmicity during ageing might lead to an increase in apoptotic processes, contributing to OA pathogenesis.

Genes encoding matrix-degrading enzymes such as Adamts4 and Mmp14 were also found to be rhythmic in murine cartilage (Gossan et al. 2013, Honda et al. 2013). ADAMTS4 is one of the major proteases responsible for the degradation of cartilage proteoglycans, namely aggrecan (Verma \& Dalal 2011). In human cartilage, this aggrecanase can be induced by proinflammatory cytokines and is upregulated in OA (Roach et al. 2005, Naito et al. 2007, Song et al. 2007). Another important protease is MMP14, a membrane-anchored enzyme that modulates the cellular availability of TGF- $\beta$ (VelascoLoyden et al. 2004) and participates in the activation of other metalloproteinases, namely MMP13 and MMP9, potentially amplifying its role in arthritis (Knäuper et al. 2002, Chellaiah \& Ma 2013). Ablation of Mmp14 led to the development of severe arthritis in ageing mice that resembles both murine collagen-induced arthritis and human RA (Holmbeck et al. 1999).

Serum levels of parathyroid hormone (PTH) exhibit a circadian variation, with a peak occurring in the early 
morning (Jubiz et al. 1972, Fuleihan et al. 1997). In mouse, bioluminescence imaging has shown that PTH is capable of resetting PER2::Luc circadian oscillations in a time- and dose-dependent manner in the femoral head growth plate (Okubo et al. 2015). Both PTH and PTHrP (parathyroid hormone-related peptide) can exert physiological effects through PTH1R (PTH 1 receptor), a receptor that is expressed in the femoral head growth plate of mice (Okubo et al. 2015). The rate of chondrocyte differentiation is modulated by a negative feedback loop involving Indian hedgehog (IHH) and PTHrP. IHH, which is secreted by newly formed hypertrophic chondrocytes, stimulated the expression of PTHrP, which in turn retarded the formation of these cells (Vortkamp et al. 1996). Remarkably, expression of Ihh in the growth plate of mice exhibited circadian variation; and Bmal1-/- mice had decreased expression of $I h h$ in the growth plate (Table 1) (Takarada et al. 2012). In light of this evidence, it has been suggested that PTHrP also conveys time information to articular chondrocytes (Okubo et al. 2015), although definitive evidence is still lacking.

\section{Bone}

Bone is a specialised connective tissue that provides mechanical integrity for locomotion, protection to vital organs (e.g. brain, heart and lungs) and encloses the medullary cavities containing bone marrow wherein haematopoiesis occurs (Morgan et al. 2013, Ho et al. 2015). It also functions as a calcium and phosphate reservoir, being involved in the metabolic pathways associated with mineral homeostasis (Copp \& Shim 1963). Bone is predominantly composed of inorganic materials of which calcium hydroxyapatite is the most abundant; the organic component, which is embedded in the calcified bone matrix, is enriched in type I collagen, but also includes proteoglycans, glycoproteins and calcium-binding proteins (Morgan et al. 2013).

To preserve its function and structure, bone undergoes two processes, modelling and remodelling, which depend on the coordinated action of the three major cell types present in the adult skeleton: osteoblasts, osteocytes and osteoclasts (Allen \& Burr 2014). In bone modelling, the uncoupled action of osteoblasts and osteoclasts on separate surfaces ensures appropriate bone morphology and mass; it occurs primarily during childhood and at low rates throughout adult life in response to changes in mechanical loading (Allen \& Burr 2014, Bartl \& Bartl 2017). In contrast, bone remodelling is characterised by the coupled action of osteoclasts and osteoblasts on the same surface; it takes place in the mature skeleton as an adaption to mechanical loading and calcium and phosphate metabolism (Allen \& Burr 2014, Bartl \& Bartl 2017). Bone homeostasis can only be maintained when there is a strict temporal control of osteoclast-mediated bone resorption and osteoblast-mediated bone formation.

\section{Evidence of circadian rhythms in bone}

Initial studies into the circadian regulation of bone metabolism revealed that bone formation is diurnally regulated in rat metaphyseal bone; the most intense period of bone matrix mineralisation occurred during the night-time and was in antiphase with matrix synthesis (Simmons \& Nichols 1966, Russell et al. 1984, Igarashi et al. 2013). Diurnal variations in the levels of serum markers of bone metabolism have also been reported, including $\mathrm{N}$ - and C-telopeptide, osteocalcin, pyridinoline, FGF23, tartrate-resistant acid phosphatase, alkaline phosphatase, calcium, phosphorus, calcitonin and PTH (Gundberg et al. 1985, Greenspan et al. 1997, Srivastava et al. 2001, Shao et al. 2003, Kawai et al. 2014, Swanson et al. 2017).

More recently, peripheral clocks in bone have been investigated at the molecular level. Transcriptome analysis of cavarial bone from mice kept in a 12-h light/12-h darkness cycle revealed that $26 \%$ of the genes represented on the microarray exhibited a circadian expression profile (Zvonic et al. 2007). Many of these rhythmic genes were related to bone metabolism, including genes involved in BMP-, Wnt- and FGF-mediated signalling, as well as genes encoding matrix structural components (e.g. fibrillins and collagens) and remodelling enzymes (e.g. Adamts1, Adamts3 and Adamts5) (Zvonic et al. 2007, Yang \& Meng 2016). To the best of our knowledge, genome-wide circadian transcriptome/proteome studies have not been performed in long bones or cells derived from it. Nonetheless, robust circadian oscillations of PER2::Luc have been identified in ex vivo cultures of both long (proximal femoral ends and radiuses) and flat bones (calvariae and scapulae) (Okubo et al. 2013). Despite these progresses, evidence for sustained molecular circadian rhythms in isolate bone cells (osteoblasts, osteoclasts and osteocytes) remains lacking.

\section{Links between dysregulation of circadian rhythms and bone homeostasis}

The molecular clock is an important regulator of bone metabolism and circadian rhythm disruption has 
been increasingly recognised as a contributing factor to pathophysiological changes in bone. For instance, population-based studies indicated that rotating shift work, which is characterised by a chronic and repeated misalignment between internal clock time and external time cues, was associated with low bone mineral density in trabecular and cortical bones (Quevedo \& Zuniga 2010), and a greater risk of hip and wrist fractures (Feskanich et al. 2009).

Leptin is a hormone predominantly secreted by adipocytes that participates in the regulation of bone remodelling, acting both on osteoblasts and osteoclasts to maintain bone mass constant (Ducy et al. 2000, Takeda et al. 2002, Elefteriou et al. 2005). Interestingly, mice lacking Per1 and either Per2 (Per1-/-Per2-/-) or the Per2 Per-Arnt-Sim (PAS) domain (Per1-/-Per2 ${ }^{m / m}$ ) presented a significant increase in bone mass that affected vertebrae and long bones, suggesting that bone remodelling could be under circadian control (Table 2) (Fu et al. 2005). Cry $1^{-/-C r y 2^{-/}}$mice also exhibited a similar phenotype (Fu et al. 2005). Biochemical and histomorphometric analyses established that this high bone mass phenotype was linked to an increase in the number of osteoblasts, increased mineral apposition and bone formation rate (Fu et al. 2005). Evidence was also presented that leptinmediated modulation of osteoblast function comprises two antagonistic pathways: on one hand, signalling through $\beta 2$-adrenergic receptors upregulated Per1 and Per2, which in turn supressed the expression of G1 cyclins and osteoblast proliferation; on the other hand, leptin acted through the AP-1 family of transcription factors to stimulate osteoblast proliferation and bone formation

Table 2 Summary of the phenotypes observed in bone from mouse models deficient in core circadian clock components.

\begin{tabular}{|c|c|c|c|}
\hline Mouse strain & Phenotype & Molecular changes & References \\
\hline \multirow[t]{5}{*}{ Bmal1-/- } & $\begin{array}{l}\text { Ectopic ossification of tendons and } \\
\text { ligaments associated with bone } \\
\text { insertion sites }\end{array}$ & Not shown & (Bunger et al. 2005) \\
\hline & $\begin{array}{l}\text { Increased rates of bone formation and } \\
\text { mineral apposition } \\
\text { Increased number of osteoblasts }\end{array}$ & Not shown & (Fu et al. 2005) \\
\hline & \multirow[t]{2}{*}{ Low bone mass } & Not shown & $\begin{array}{l}\text { (Kondratov et al. 2006, Samsa } \\
\text { et al. 2016, Takarada et al. } \\
\text { 2017) }\end{array}$ \\
\hline & & $\begin{array}{l}\text { Increased expression of } \mathrm{Mmp9} \text {, } \\
\text { CatK, Trap, Rank, Calcr and } \\
\text { Rankl in femur }\end{array}$ & (Takarada et al. 2017) \\
\hline & $\begin{array}{l}\text { Decreased number of active } \\
\text { osteoblasts and osteocytes } \\
\text { Reduced ability of bone marrow } \\
\text { mesenchymal stem cells to } \\
\text { differentiate into osteoblasts }\end{array}$ & Not shown & (Samsa et al. 2016) \\
\hline Bmal1osc-/- & $\begin{array}{l}\text { High bone mass } \\
\text { Reduced bone resorption }\end{array}$ & $\begin{array}{l}\text { Decreased expression of Acp5 } \\
\text { and Nfatc1 }\end{array}$ & (Xu et al. 2016) \\
\hline Bmal10sx-/- & $\begin{array}{l}\text { Low bone mass } \\
\text { Increased bone resorption }\end{array}$ & Not shown & (Takarada et al. 2017) \\
\hline Per1-/-Per2-/- & \multirow{3}{*}{$\begin{array}{l}\text { High bone mass } \\
\text { Increased number of osteoblasts, } \\
\text { mineral apposition and bone } \\
\text { formation rate }\end{array}$} & Not shown & (Fu et al. 2005) \\
\hline Per1-/-Per2 ${ }^{m / m}$ & & $\begin{array}{l}\text { Decreased expression of Bmal1, } \\
\text { Clock, Cry1, Per1, Per2 and Osx } \\
\text { Increased expression of Ccnd1, } \\
\text { Ccnd3, Ccne, c-Fos, JunB and } \\
\text { Fra2 }\end{array}$ & \\
\hline Cry1-/-Cry2-/- & & Not shown & \\
\hline Per2m/m & $\begin{array}{l}\text { High bone mass } \\
\text { Increased osteoblast number and } \\
\text { bone formation rate }\end{array}$ & Not shown & (Maronde et al. 2010) \\
\hline \multirow[t]{2}{*}{ Cryz-/- } & High bone mass & Not shown & \\
\hline & $\begin{array}{l}\text { Normal osteoblast number, but } \\
\text { decreased osteoclast activity }\end{array}$ & & \\
\hline $\begin{array}{l}\text { https://joe.bioscie } \\
\text { https://doi.org/10. }\end{array}$ & $\begin{array}{l}\text { (c) } 2019 \text { Society for Endocrinology } \\
\text { Published by Bioscientifica Ltd. } \\
\text { Printed in Great Britain }\end{array}$ & Downloaded from & ica.com \\
\hline
\end{tabular}


(de Crombrugghe 2005, Fu et al. 2005). A subsequent study performed in $\mathrm{Per} 2^{\mathrm{m} / \mathrm{m} C r y 2^{-/-}}$mice indicated that these clock genes affect distinct bone formation pathways, with Cry 2 and Per2 modulating osteoclast and osteoblast function, respectively (Table 2) (Maronde et al. 2010).

In adult mice, ablation of Bmal1 resulted in a low bone mass phenotype that is characterised by significant reductions in bone mineral density and volume (Table 2) (Kondratov et al. 2006, Samsa et al. 2016, Takarada et al. 2017). These mice had a significantly lower number of active osteoblasts and osteocytes than wild-type littermates, which could be explained by a reduced ability of bone marrow mesenchymal stem cells to differentiate into osteoblasts (Samsa et al. 2016). Moreover, it has been reported that BMAL1 is involved in osteoclastogenesis by regulating the calcitriol-induced expression of Rankl in osteoblasts (Takarada et al. 2017). These findings contrast another study in Bmal1-/- adolescent mice that showed an increase in the number of osteoblasts, accompanied by increased rates of bone formation and mineral apposition (Fu et al. 2005). A recent study showed that tamoxifen-induced post-natal ablation of Bmal1 in adult mice did not recapitulate the skeletal phenotype presented by Bmal1-/- (Yang et al. 2016b). Altogether, these data suggest BMAL1 could have distinct roles in the regulation of bone homeostasis throughout development and post-natal stages.

The role of BMAL1 in bone remodelling processes is not limited to osteoblasts. In mice, targeted deletion of Bmal1 in osteoclasts led to the development of a high bone mass phenotype (Table 2) (Xu et al. 2016). The observed reduction in bone resorption was related to the direct upregulation of $\mathrm{Nfatc1}$, a master regulator of osteoclast differentiation, by the CLOCK-BMAL1 complex (Kim \& Kim 2014, Xu et al. 2016). Furthermore, it was demonstrated that expression of BMAL1 is reduced in bone marrow cells isolated from a type 2 diabetes rat model (Li et al. 2018). Complementary in vitro studies suggested that this core clock protein fine tunes the equilibrium between osteogenesis and osteoclastogenesis through modulation of the NF-кB signalling pathway (Li et al. 2018).

Hypophosphatemia during skeletal development impairs the mitochondria-mediated apoptosis of hypertrophic chondrocytes, leading to abnormal growth plate maturation and bone mineralisation (Sabbagh et al. 2005, Miedlich et al. 2010). Expression of clock genes in fracture calluses from hypophosphataemic mice was higher than that in control littermates, suggesting that phosphate metabolism is involved in the regulation of the circadian clock in bone (Noguchi et al. 2018).
Remarkably, network analysis identified Ezh2 (enhancer of zeste homolog 2), a key epigenetic regulator of skeletal longitudinal growth, as one of the main molecules associated with hypophosphatemia (Dudakovic et al. 2015, Lui et al. 2016, Noguchi et al. 2018). Previous work revealed that EZH2 binds to the promoter region of Per1 and Per2; and targeted silencing of this histone methyltransferase disrupted circadian rhythms (Etchegaray et al. 2006). In adolescent mice, ablation of Ezh2 in bone marrow nestinexpressing cells resulted in premature cellular senescence and a depleted pool of mesenchymal progenitor cells; this was associated with impaired osteogenesis and a higher risk of developing osteoporosis later in life (Li et al. 2017).

Besides controlling mineral homeostasis, the skeleton is also an active modulator of energy metabolism (Kawai \& Rosen 2010). CLOCK-BMAL1 heterodimers directly control the expression of Noc (nocturnin), a RNA deadenylase that participates in the post-transcriptional regulation of metabolic genes (Li et al. 2008, Stubblefield et al. 2012). In vitro studies demonstrated that Noc modulates the fate of bone marrow stromal cells by promoting adipogenesis and suppressing osteoblastogenesis (Kawai et al. 2010a). $\mathrm{Noc}^{-/-}$mice presented a high bone mass phenotype and a reduced number of adipocytes in the bone marrow, indicating a shift in stromal cell differentiation that favours osteoblastogenesis (Kawai et al. 2010a, Guntur et al. 2011). NOC has been shown to bind to PPAR $\gamma$ (peroxisome proliferator-activated receptor $\gamma$ ), promoting its nuclear translocation and activity (Kawai et al. 2010a). $\operatorname{PPAR} \gamma$ activation favoured the differentiation of bone stromal cells into adipocytes and supressed osteogenic signalling pathways such as BMP, TGF- $\beta$ and WNT, as well as osteoblast-specific transcription factors (e.g. Runx2, Sox9, and Sp7) (Shockley et al. 2009). In vivo silencing of Pparg caused a reduction in the number of bone marrow adipocytes that was accompanied by increased trabecular bone formation (James et al. 2014). Furthermore, overexpression of the clock gene Rev-erba (a direct target of PPAR $\gamma$ ) in bone mesenchymal stem cells inhibited cell proliferation and osteogenesis (Fontaine et al. 2003, He et al. 2015).

IGF-1 (insulin-like growth factor type 1) is an anabolic factor that plays an important role in the differentiation of mesenchymal stem cells into osteoblasts (Xian et al. 2012, Crane et al. 2013). In mouse femur, circadian expression of Igf1 was in antiphase with the clock-regulated transcription of Noc; and NOC was shown to interacting with the longer form of the $3^{\prime}$ untranslated region of $I g f 1$ to reduce the expression of this growth factor (Kawai et al. 2010b). Circadian rhythms in IGF-1 signalling were 
perturbed in Cry-deficient mice; and it was proposed that CRY-mediated regulation of STAT5B (signal transducer and activator of transcription 5) phosphorylation could mediate the downregulation of Igf1 (Chaudhari et al. 2017). Moreover, IGF-1 can induce the phosphorylation of PTH1R in vitro, enhancing osteoblast to osteocyte transition and providing another link between the circadian clock, IGF-1 and PTH (Jubiz et al. 1972, Fuleihan et al. 1997, Qiu et al. 2018). More recently, it has been demonstrated that IGF-1-mediated signalling is sufficient to modulate the phase and amplitude of circadian rhythms in vivo and in vitro through increased PER synthesis (Crosby et al. 2019); future studies should seek to investigate whether these mechanisms are also relevant for skeletal homeostasis.

Systemic signalling through glucocorticoids is also a fundamental time cue for the circadian regulation of bone homeostasis. The addition of dexamethasone, a glucocorticoid hormone analogue, to osteoblasts and osteoclasts stimulated the rhythmic mRNA expression of circadian genes, as revealed by time course qPCR (Komoto et al. 2012, Fujihara et al. 2014). The circadian profile of osteoclast-specific genes such as Ctsk and Nfatc1 disappeared in bone tissue from adrenalectomised mice; and these oscillations were restored by intraperitoneal injection of dexamethasone (Fujihara et al. 2014). In addition, overexpression of the transcriptional regulator Gilz (glucocorticoid-induced leucine zipper) enhanced osteogenic differentiation of bone marrow stromal cells in vitro by blocking the transcription of Pparg (Shi et al. 2003, Zhang et al. 2008, Pan et al. 2014).

\section{Clinical relevance of circadian biology for skeletal disorders}

The numerous connections between the circadian clock and skeletal homeostasis bring about the possibility of targeting circadian rhythms to improve existing therapies and develop new routes. One approach is to adopt the concept of 'chronotherapy', in which the drug regimen is tailored to a patient's circadian rhythm in order to maximise treatment effectiveness and reduce adverse effects (Selfridge et al. 2016). Over 40 years ago, it was reported that $\mathrm{OA}$ and RA symptoms can be improved by timing the intake of indomethacin and flurbiprofen; and treatment efficiency was correlated with the individual circadian variation of pain (Huskisson et al. 1970, Kowanko et al. 1981, Levi et al. 1985). More recently, it was demonstrated that timing teriparatide dosing affected the circadian rhythms of bone resorption markers in postmenopausal osteoporotic women (Luchavova et al. 2011). One of the most compelling examples of how circadian biology could be important when defining chronotherapeutic strategies comes from the use of glucocorticoids to treat RA. A landmark study revealed that coordinating glucocorticoid administration with the nocturnal rise in circulating levels of IL-6 substantially reduced joint pain and stiffness in comparison to standard morning administration (Arvidson et al. 1997). Subsequent clinical trials with modified-release prednisone which enables convenient bedtime administration demonstrated that this timed drug delivery noticeably increased treatment response rates and improved physical function (Buttgereit et al. $2008,2010,2013)$. These results emphasise the importance of implementing chronotherapy when designing clinical trials and evaluating treatment outcomes.

Another strategy to treat circadian disruptions is to use small molecules that directly target the clock or closely related pathways (Wallach \& Kramer 2015). As the circadian clock is involved in the regulation of a multitude of signalling pathways, this approach might prove advantageous in comparison to polytherapy wherein two or more drugs are used to target distinct pathways. In fact, several compounds targeting clock proteins such as CRY1/2 and ROR have already been described, with beneficial effects in animal models for metabolic diseases (Hirota et al. 2012, He et al. 2016, Dierickx et al. 2019). For example, nobiletin is a naturally occurring polymethoxylated flavone present in citrus peels that enhances the amplitude of circadian rhythms in mouse (He et al. 2016). Remarkably, treatment of diet-induced obese mouse with nobiletin counteracted metabolic syndrome and increased energy expenditure and locomotor activity (He et al. 2016). RORs were identified as direct protein targets for nobiletin, acting as an agonist and enhancing Bmal1 transcription (He et al. 2016). Additionally, synthetic REV-ERB agonists have been shown to alter circadian expression patterns of metabolic genes in the liver, skeletal muscle and adipose tissue; and these changes resulted in increased energy expenditure (Solt et al. 2012). In the case of skeletal disorders, the therapeutic potential of small-molecule modulators remains largely unexplored; yet, these compounds offer promising approaches to modulate circadian timing and restore cellular homeostasis.

Lastly, behavioural interventions such as the maintenance of robust daily schedules in feeding and sleep/ wake cycles have been increasingly recognised as potential approaches to strengthen circadian rhythms (Schroeder \& Colwell 2013, Longo \& Panda 2016). However, peripheral 
clocks seem to have evolved distinctive entrainment mechanisms by which the endogenous circadian clock is reset or synchronised with exogenous time cues, indicating the need to identify tissue-specific time cues (Guo et al. 2005, Izumo et al. 2014). Molecular components of the circadian clock have previously been identified as mechanosensitive in mammals and fruit flies (Kanbe et al. 2006, Simoni et al. 2014). In skeletal disorders, a balanced physical exercise schedule has been shown to be effective in improving musculoskeletal functions and reducing symptom severity (Roddy et al. 2005, Cooney et al. 2011, Moreira et al. 2014). From a circadian viewpoint, it is worth considering not only the duration and frequency of exercise, but also its timing; scheduled exercise that is optimised according to an individual's chronotype, a human attribute that defines whether an individual prefers to be active and alert during the morning versus evening, is likely to be more effective than the random and irregular practice of physical exercise (Riley \& Esser 2017, Duglan \& Lamia 2019).

\section{Concluding remarks}

In modern $24 / 7$ societies, the prevalence of circadian rhythm disruption is rising as more and more people have adopted nocturnal lifestyles. Nonetheless, circadian rhythm disruption is yet to be recognised as a major public health issue; and the circadian modulation of physiology has been largely overlooked in clinical research and practice.

Over the last decade or so, several lines of evidence have shed light onto the complex interactions between the circadian clock and the skeletal system (Fig. 3). Genomewide expression studies have established molecular clocks as pivotal modulators of the temporal segregation of metabolism in bone and cartilage cells. Studies in transgenic mouse models have linked the disruption of the molecular clock machinery to imbalances in processes such as cartilage matrix synthesis/degradation and bone formation/resorption, which often predispose the tissue to pathophysiological changes. In addition, epidemiological studies have also associated circadian rhythm disruption with a greater risk of developing skeletal disorders such as arthritis and osteoporosis.

Despite these recent advances, our understanding of the multiple levels of circadian regulation of skeletal metabolism and physiology remains largely unexplored. Future work will require conditional tissue-specific and celltype-specific inactivation or overexpression of different molecular clock components to distinguish between genespecific (e.g. during development) and post-natal clockrelated functions. In addition, epidemiological studies should account for individual chronotype variability by including stratification approaches. Although the translational applications of circadian biology are only beginning to be explored, the clinical implementation of chronotherapy to treat RA resulted in significant benefits

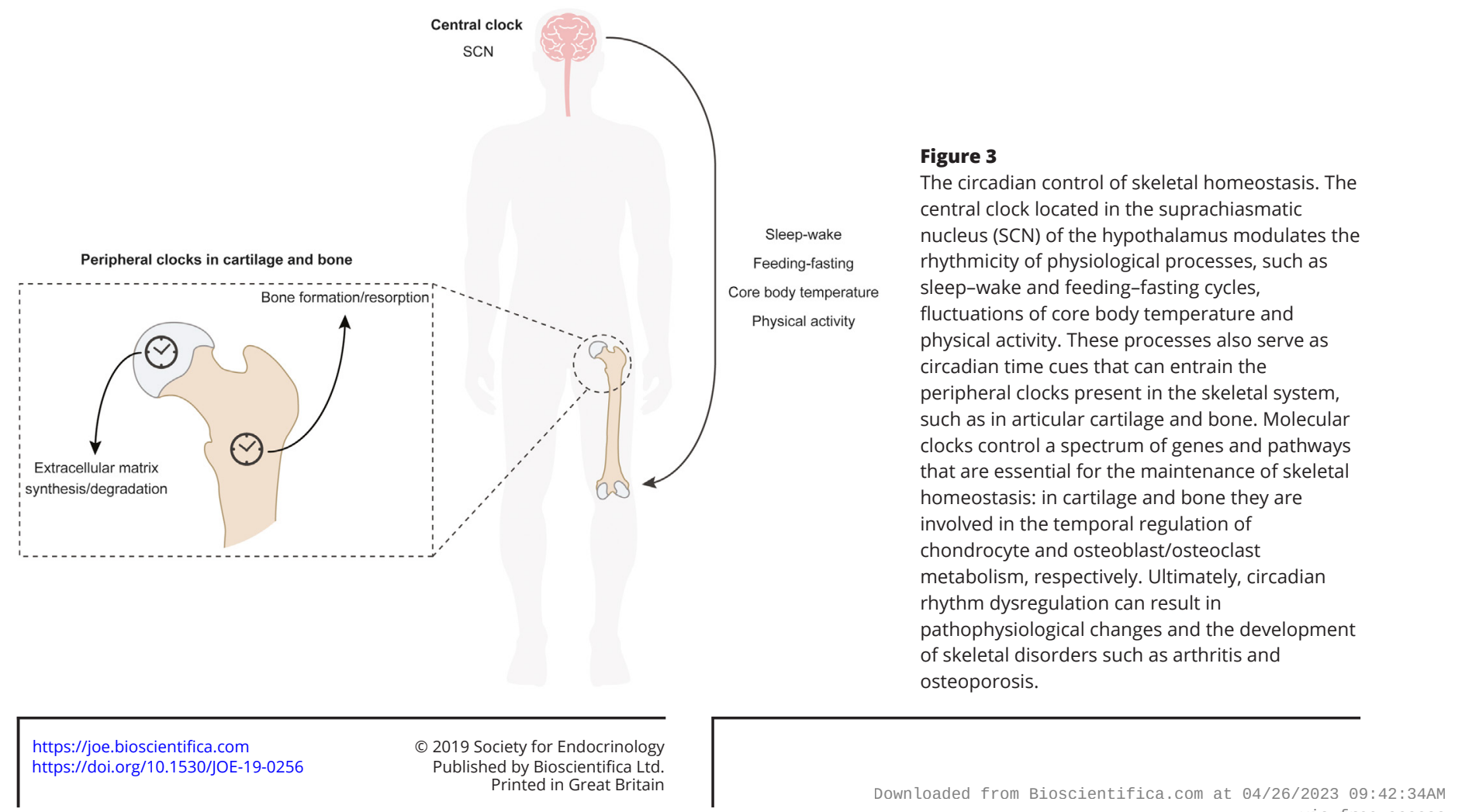


for patients. By taking into consideration the multifaceted role of the circadian clock in skeletal homeostasis, new therapies could be developed that will greatly enhance therapeutic index and bring us one step closer to precision medicine.

\section{Declaration of interest}

The authors declare that there is no conflict of interest that could be perceived as prejudicing the impartiality of this review.

\section{Funding}

This work was supported by an Arthritis Research UK (Versus Arthritis) Senior Research Fellowship Award (20875); an MRC project grant (MR/ K019392/1); a Wellcome Trust PhD studentship to C F G (215205/Z/19/Z); and Wellcome Trust funding for The Wellcome Centre for Cell-Matrix Research (088785/Z/09/Z).

\section{References}

Akagi R, Akatsu Y, Fisch KM, Alvarez-Garcia O, Teramura T, Muramatsu Y, Saito M, Sasho T, Su AI \& Lotz MK 2017 Dysregulated circadian rhythm pathway in human osteoarthritis: NR1D1 and BMAL1 suppression alters TGF- $\beta$ signaling in chondrocytes. Osteoarthritis and Cartilage 25 943-951. (https://doi.org/10.1016/j.joca.2016.11.007)

Albrecht U 2012 Timing to perfection: the biology of central and peripheral circadian clocks. Neuron 74 246-260. (https://doi. org/10.1016/j.neuron.2012.04.006)

Allen MR \& Burr DB 2014 Bone modeling and remodeling. In Basic and Applied Bone Biology, Chapter 4, pp 75-90. Eds DB Burr \& MR Allen. San Diego, CA, USA: Academic Press. (https://doi.org/10.1016/B978-012-416015-6.00004-6)

Andersson MLE, Petersson IF, Karlsson KE, Jonsson EN, Månsson B, Heinegård D \& Saxne T 2006 Diurnal variation in serum levels of cartilage oligomeric matrix protein in patients with knee osteoarthritis or rheumatoid arthritis. Annals of the Rheumatic Diseases 65 1490-1494. (https://doi.org/10.1136/ard.2005.051292)

Archer CW \& Francis-West P 2003 The chondrocyte. International Journal of Biochemistry and Cell Biology 35 401-404. (https://doi.org/10.1016/ S1357-2725(02)00301-1)

Arvidson NG, Gudbjornsson B, Larsson A \& Hallgren R 1997 The timing of glucocorticoid administration in rheumatoid arthritis. Annals of the Rheumatic Diseases 56 27-31. (https://doi.org/10.1136/ard.56.1.27)

Balsalobre A, Brown SA, Marcacci L, Tronche F, Kellendonk C, Reichardt HM, Schütz G \& Schibler U 2000 Resetting of circadian time in peripheral tissues by glucocorticoid signaling. Science $\mathbf{2 8 9}$ 2344-2347. (https://doi.org/10.1126/science.289.5488.2344)

Bartl R \& Bartl C 2017 Modelling and remodelling of bone. In Bone Disorders : Biology, Diagnosis, Prevention, Therapy, pp 21-30. Eds R Bartl \& C Bartl. Cham, Switzerland: Springer International Publishing. (https://doi.org/10.1007/978-3-319-29182-6_3)

Bell-Pedersen D, Cassone VM, Earnest DJ, Golden SS, Hardin PE, Thomas TL \& Zoran MJ 2005 Circadian rhythms from multiple oscillators: lessons from diverse organisms. Nature Reviews: Genetics 6 544-556. (https://doi.org/10.1038/nrg1633)

Berenbaum F \& Meng QJ 2016 The brain-joint axis in osteoarthritis: nerves, circadian clocks and beyond. Nature Reviews: Rheumatology 12 508-516. (https://doi.org/10.1038/nrrheum.2016.93)
Blaney Davidson EN, Scharstuhl A, Vitters EL, van der Kraan PM \& van den Berg WB 2005 Reduced transforming growth factor-beta signaling in cartilage of old mice: role in impaired repair capacity. Arthritis Research and Therapy 7 R1338-R1347. (https://doi.org/10.1186/ar1833)

Blaney Davidson EN, Remst DFG, Vitters EL, van Beuningen HM, Blom AB, Goumans MJ, van den Berg WB \& van der Kraan PM 2009 Increase in ALK1/ALK5 ratio as a cause for elevated MMP13 expression in osteoarthritis in humans and mice. Journal of Immunology 182 7937-7945. (https://doi.org/10.4049/ jimmunol.0803991)

Bohensky J, Shapiro IM, Leshinsky S, Terkhorn SP, Adams CS \& Srinivas V 2007 HIF-1 regulation of chondrocyte apoptosis: induction of the autophagic pathway. Autophagy 3 207-214. (https://doi.org/10.4161/ auto.3708)

Bohensky J, Terkhorn SP, Freeman TA, Adams CS, Garcia JA, Shapiro IM \& Srinivas V 2009 Regulation of autophagy in human and murine cartilage: hypoxia-inducible factor 2 suppresses chondrocyte autophagy. Arthritis and Rheumatism 60 1406-1415. (https://doi. org/10.1002/art.24444)

Böhm B, Hess S, Krause K, Schirner A, Ewald W, Aigner T \& Burkhardt H 2010 ADAM15 exerts an antiapoptotic effect on osteoarthritic chondrocytes via up-regulation of the X-linked inhibitor of apoptosis. Arthritis and Rheumatism 62 1372-1382. (https://doi.org/10.1002/ art.27387)

Buhr ED \& Takahashi JS 2013 Molecular components of the mammalian circadian clock. Handbook of Experimental Pharmacology 217 3-27. (https://doi.org/10.1007/978-3-642-25950-0_1)

Buijs FN, Cazarez F, Basualdo MC, Scheer FA, Perusquía M, Centurion D \& Buijs RM 2014 The suprachiasmatic nucleus is part of a neural feedback circuit adapting blood pressure response. Neuroscience 266 197-207. (https://doi.org/10.1016/j.neuroscience.2014.02.018)

Bunger MK, Walisser JA, Sullivan R, Manley PA, Moran SM, Kalscheur VL, Colman RJ \& Bradfield CA 2005 Progressive arthropathy in mice with a targeted disruption of the Mop3/Bmal-1 locus. Genesis 41 122-132. (https://doi.org/10.1002/gene.20102)

Buttgereit F, Doering G, Schaeffler A, Witte S, Sierakowski S, GromnicaIhle E, Jeka S, Krueger K, Szechinski J \& Alten R 2008 Efficacy of modified-release versus standard prednisone to reduce duration of morning stiffness of the joints in rheumatoid arthritis (CAPRA-1): a double-blind, randomised controlled trial. Lancet 371 205-214. (https://doi.org/10.1016/S0140-6736(08)60132-4)

Buttgereit F, Doering G, Schaeffler A, Witte S, Sierakowski S, GromnicaIhle E, Jeka S, Krueger K, Szechinski J \& Alten R 2010 Targeting pathophysiological rhythms: prednisone chronotherapy shows sustained efficacy in rheumatoid arthritis. Annals of the Rheumatic Diseases 69 1275-1280. (https://doi.org/10.1136/ard.2009.126888)

Buttgereit F, Mehta D, Kirwan J, Szechinski J, Boers M, Alten RE, Supronik J, Szombati I, Romer U, Witte S, et al. 2013 Low-dose prednisone chronotherapy for rheumatoid arthritis: a randomised clinical trial (CAPRA-2). Annals of the Rheumatic Diseases 72 204-210. (https://doi.org/10.1136/annrheumdis-2011-201067)

Caramés B, Taniguchi N, Seino D, Blanco FJ, D’Lima D \& Lotz M 2012 Mechanical injury suppresses autophagy regulators and pharmacologic activation of autophagy results in chondroprotection. Arthritis and Rheumatism 64 1182-1192. (https://doi.org/10.1002/art.33444)

Challet E \& Pévet P 2003 Interactions between photic and nonphotic stimuli to synchronize the master circadian clock in mammals. Frontiers in Bioscience 8 s246-s257. (https://doi.org/10.2741/1039)

Chaudhari A, Gupta R, Patel S, Velingkaar N \& Kondratov R 2017 Cryptochromes regulate IGF-1 production and signaling through control of JAK2-dependent STAT5B phosphorylation. Molecular Biology of the Cell 28 834-842. (https://doi.org/10.1091/mbc.E16-08-0624)

Chellaiah MA \& Ma T 2013 Membrane localization of membrane type 1 matrix metalloproteinase by CD44 regulates the activation of pro-matrix metalloproteinase 9 in osteoclasts. BioMed Research International 2013 302392. (https://doi.org/10.1155/2013/302392) 
Cooney JK, Law RJ, Matschke V, Lemmey AB, Moore JP, Ahmad Y, Jones JG, Maddison P \& Thom JM 2011 Benefits of exercise in rheumatoid arthritis. Journal of Aging Research 2011 681640. (https:// doi.org/10.4061/2011/681640)

Copp DH \& Shim SS 1963 The homeostatic function of bone as a mineral reservoir. Oral Surgery, Oral Medicine, and Oral Pathology 16 738-744. (https://doi.org/10.1016/0030-4220(63)90081-1)

Crane JL, Zhao L, Frye JS, Xian L, Qiu T \& Cao X 2013 IGF-1 signaling is essential for differentiation of mesenchymal stem cells for peak bone mass. Bone Research 1 186-194. (https://doi.org/10.4248/BR201302007)

Crosby P, Hamnett R, Putker M, Hoyle NP, Reed M, Karam CJ, Maywood ES, Stangherlin A, Chesham JE, Hayter EA, et al. 2019 Insulin/IGF-1 drives PERIOD synthesis to entrain circadian rhythms with feeding time. Cell 177 896.e20-909.e20. (https://doi. org/10.1016/j.cell.2019.02.017)

Davis FC \& Gorski RA 1988 Development of hamster circadian rhythms: role of the maternal suprachiasmatic nucleus. Journal of Comparative Physiology: A, Sensory, Neural, and Behavioral Physiology 162 601-610. (https://doi.org/10.1007/BF01342635)

de Crombrugghe B 2005 Osteoblasts clock in for their day job. Cell 122 651-653. (https://doi.org/10.1016/j.cell.2005.08.025)

Dibner C, Schibler U \& Albrecht U 2010 The mammalian circadian timing system: organization and coordination of central and peripheral clocks. Annual Review of Physiology 72 517-549. (https:// doi.org/10.1146/annurev-physiol-021909-135821)

Dierickx P, Emmett MJ, Jiang C, Uehara K, Liu M, Adlanmerini M \& Lazar MA 2019 SR9009 has REV-ERB-independent effects on cell proliferation and metabolism. PNAS 116 12147-12152. (https://doi. org/10.1073/pnas.1904226116)

Ducy P, Amling M, Takeda S, Priemel M, Schilling AF, Beil FT, Shen J, Vinson C, Rueger JM \& Karsenty G 2000 Leptin inhibits bone formation through a hypothalamic relay: a central control of bone mass. Cell 100 197-207. (https://doi.org/10.1016/s00928674(00)81558-5)

Dudakovic A, Camilleri ET, Xu F, Riester SM, McGee-Lawrence ME, Bradley EW, Paradise CR, Lewallen EA, Thaler R, Deyle DR, et al. 2015 Epigenetic control of skeletal development by the histone methyltransferase Ezh2. Journal of Biological Chemistry $29027604-$ 27617. (https://doi.org/10.1074/jbc.M115.672345)

Dudek M \& Meng QJ 2014 Running on time: the role of circadian clocks in the musculoskeletal system. Biochemical Journal 463 1-8. (https:// doi.org/10.1042/BJ20140700)

Dudek M, Gossan N, Yang N, Im H-J, Ruckshanthi JPD, Yoshitane H, Li X, Jin D, Wang P, Boudiffa M, et al. 2016 The chondrocyte clock gene Bmal1 controls cartilage homeostasis and integrity. Journal of Clinical Investigation 126 365-376. (https://doi.org/10.1172/JCI82755)

Dudek M, Yang N, Ruckshanthi JP, Williams J, Borysiewicz E, Wang P, Adamson A, Li J, Bateman JF, White MR, et al. 2017 The intervertebral disc contains intrinsic circadian clocks that are regulated by age and cytokines and linked to degeneration. Annals of the Rheumatic Diseases 76 576-584. (https://doi.org/10.1136/annrheumdis-2016-209428)

Duglan D \& Lamia KA 2019 Clocking in, working out: circadian regulation of exercise physiology. Trends in Endocrinology and Metabolism 30 347-356. (https://doi.org/10.1016/j.tem.2019.04.003)

Eastman CI, Mistlberger RE \& Rechtschaffen A 1984 Suprachiasmatic nuclei lesions eliminate circadian temperature and sleep rhythms in the rat. Physiology and Behavior 32 357-368. (https://doi. org/10.1016/0031-9384(84)90248-8)

Elefteriou F, Ahn JD, Takeda S, Starbuck M, Yang X, Liu X, Kondo H, Richards WG, Bannon TW, Noda M, et al. 2005 Leptin regulation of bone resorption by the sympathetic nervous system and CART. Nature 434 514-520. (https://doi.org/10.1038/nature03398)

Etchegaray JP, Yang X, DeBruyne JP, Peters AHFM, Weaver DR, Jenuwein T \& Reppert SM 2006 The polycomb group protein EZH2 is required for mammalian circadian clock function. Journal of Biological Chemistry 281 21209-21215. (https://doi.org/10.1074/jbc.M603722200)
Feskanich D, Hankinson SE \& Schernhammer ES 2009 NightShift work and fracture risk: the Nurses' Health Study. Osteoporosis International 20 537-542. (https://doi.org/10.1007/s00198-008-0729-5)

Finnson KW, Chi Y, Bou-Gharios G, Leask A \& Philip A 2012 TGF- $\beta$ signaling in cartilage homeostasis and osteoarthritis. Frontiers in Bioscience 4 251-268. (https://doi.org/10.2741/s266)

Fontaine C, Dubois G, Duguay Y, Helledie T, Vu-Dac N, Gervois P, Soncin F, Mandrup S, Fruchart JC, Fruchart-Najib J, et al. 2003 The orphan nuclear receptor Rev-Erbalpha is a peroxisome proliferator-activated receptor (PPAR) gamma target gene and promotes PPARgamma-induced adipocyte differentiation. Journal of Biological Chemistry 278 37672-37680. (https://doi.org/10.1074/jbc. M304664200)

Fortier LA \& Miller BJ 2006 Signaling through the small G-protein Cdc42 is involved in insulin-like growth factor-I resistance in aging articular chondrocytes. Journal of Orthopaedic Research 24 1765-1772. (https:// doi.org/10.1002/jor.20185)

Fu L, Patel MS, Bradley A, Wagner EF \& Karsenty G 2005 The molecular clock mediates leptin-regulated bone formation. Cell 122 803-815. (https://doi.org/10.1016/j.cell.2005.06.028)

Fujihara Y, Kondo H, Noguchi T \& Togari A 2014 Glucocorticoids mediate circadian timing in peripheral osteoclasts resulting in the circadian expression rhythm of osteoclast-related genes. Bone 61 1-9. (https:// doi.org/10.1016/j.bone.2013.12.026)

Fuleihan GE-H, Klerman EB, Brown EN, Choe Y, Brown EM \& Czeisler CA 1997 The parathyroid hormone circadian rhythm is truly endogenous - a general clinical research center study. Journal of Clinical Endocrinology and Metabolism 82 281-286. (https://doi.org/10.1210/ jcem.82.1.3683)

Gachon F, Fonjallaz P, Damiola F, Gos P, Kodama T, Zakany J, Duboule D, Petit B, Tafti M \& Schibler U 2004 The loss of circadian PAR bZip transcription factors results in epilepsy. Genes and Development 18 1397-1412. (https://doi.org/10.1101/gad.301404)

Gachon F, Olela FF, Schaad O, Descombes P \& Schibler U 2006 The circadian PAR-domain basic leucine zipper transcription factors DBP, TEF, and HLF modulate basal and inducible xenobiotic detoxification. Cell Metabolism 4 25-36. (https://doi.org/10.1016/j.cmet.2006.04.015)

Gallego M \& Virshup DM 2007 Post-translational modifications regulate the ticking of the circadian clock. Nature Reviews: Molecular Cell Biology 8 139-148. (https://doi.org/10.1038/nrm2106)

Gekakis N, Staknis D, Nguyen HB, Davis FC, Wilsbacher LD, King DP, Takahashi JS \& Weitz CJ 1998 Role of the CLOCK protein in the mammalian circadian mechanism. Science 280 1564-1569. (https:// doi.org/10.1126/science.280.5369.1564)

Gibbs JE \& Ray DW 2013 The role of the circadian clock in rheumatoid arthritis. Arthritis Research and Therapy 15 205. (https://doi. org/10.1186/ar4146)

Goldring MB \& Marcu KB 2009 Cartilage homeostasis in health and rheumatic diseases. Arthritis Research and Therapy 11 224. (https://doi. org/10.1186/ar2592)

Gooley JJ, Lu J, Chou TC, Scammell TE \& Saper CB 2001 Melanopsin in cells of origin of the retinohypothalamic tract. Nature Neuroscience $\mathbf{4}$ 1165. (https://doi.org/10.1038/nn768)

Gossan N, Zeef L, Hensman J, Hughes A, Bateman JF, Rowley L, Little CB, Piggins HD, Rattray M, Boot-Handford RP, et al. 2013 The circadian clock in murine chondrocytes regulates genes controlling key aspects of cartilage homeostasis. Arthritis and Rheumatism $652334-2345$. (https://doi.org/10.1002/art.38035)

Greenblatt MB, Ritter SY, Wright J, Tsang K, Hu D, Glimcher LH \& Aliprantis AO 2013 NFATc1 and NFATc2 repress spontaneous osteoarthritis. PNAS 110 19914-19919. (https://doi.org/10.1073/ pnas.1320036110)

Greenspan SL, Dresner-Pollak R, Parker RA, London D \& Ferguson L 1997 Diurnal variation of bone mineral turnover in elderly men and women. Calcified Tissue International 60 419-423. (https://doi. org/10.1007/s002239900256) https://joe.bioscientifica.com

https://doi.org/10.1530/JOE-19-0256 (c) 2019 Society for Endocrinology Published by Bioscientifica Ltd. Printed in Great Britain 
Gundberg CM, Markowitz ME, Mizruchi M \& Rosen JF 1985 Osteocalcin in human serum: a circadian rhythm. Journal of Clinical Endocrinology and Metabolism 60 736-739. (https://doi.org/10.1210/jcem-60-4-736)

Guntur AR, Kawai M, Le P, Bouxsein ML, Bornstein S, Green CB \& Rosen CJ 2011 An essential role for the circadian-regulated gene Nocturnin in osteogenesis: the importance of local timekeeping in skeletal homeostasis. Annals of the New York Academy of Sciences $\mathbf{1 2 3 7}$ 58-63. (https://doi.org/10.1111/j.1749-6632.2011.06213.x)

Guo H, Brewer JM, Champhekar A, Harris RBS \& Bittman EL 2005 Differential control of peripheral circadian rhythms by suprachiasmatic-dependent neural signals. PNAS 102 3111-3116. (https://doi.org/10.1073/pnas.0409734102)

Guo H, Brewer JM, Lehman MN \& Bittman EL 2006 Suprachiasmatic regulation of circadian rhythms of gene expression in hamster peripheral organs: effects of transplanting the pacemaker. Journal of Neuroscience 26 6406-6412. (https://doi.org/10.1523/ JNEUROSCI.4676-05.2006)

Hattar S, Liao HW, Takao M, Berson DM \& Yau KW 2002 Melanopsincontaining retinal ganglion cells: architecture, projections, and intrinsic photosensitivity. Science 295 1065-1070. (https://doi. org/10.1126/science.1069609)

He Y, Lin F, Chen Y, Tan Z, Bai D \& Zhao Q 2015 Overexpression of the circadian clock gene Rev-erb $\alpha$ affects murine bone mesenchymal stem cell proliferation and osteogenesis. Stem Cells and Development 24 1194-1204. (https://doi.org/10.1089/scd.2014.0437)

He B, Nohara K, Park N, Park YS, Guillory B, Zhao Z, Garcia JM, Koike N, Lee CC, Takahashi JS, et al. 2016 The small molecule nobiletin targets the molecular oscillator to enhance circadian rhythms and protect against metabolic syndrome. Cell Metabolism 23 610-621. (https:// doi.org/10.1016/j.cmet.2016.03.007)

Hirota T, Lee JW, St John PC, Sawa M, Iwaisako K, Noguchi T, Pongsawakul PY, Sonntag T, Welsh DK, Brenner DA, et al. 2012 Identification of small molecule activators of cryptochrome. Science 337 1094-1097. (https://doi.org/10.1126/science.1223710)

Ho MSH, Medcalf RL, Livesey SA \& Traianedes K 2015 The dynamics of adult haematopoiesis in the bone and bone marrow environment. British Journal of Haematology 170 472-486. (https://doi.org/10.1111/ bjh.13445)

Holmbeck K, Bianco P, Caterina J, Yamada S, Kromer M, Kuznetsov SA, Mankani M, Gehron Robey PG, Poole AR, Pidoux I, et al. 1999 MT1MMP-deficient mice develop dwarfism, osteopenia, arthritis, and connective tissue disease due to inadequate collagen turnover. Cell 99 81-92. (https://doi.org/10.1016/s0092-8674(00)80064-1)

Honda KK, Kawamoto T, Ueda HR, Nakashima A, Ueshima T, Yamada RG, Nishimura M, Oda R, Nakamura S, Kojima T, et al. 2013 Different circadian expression of major matrix-related genes in various types of cartilage: modulation by light-dark conditions. Journal of Biochemistry 154 373-381. (https://doi.org/10.1093/jb/mvt068)

Honma S 2018 The mammalian circadian system: a hierarchical multioscillator structure for generating circadian rhythm. Journal of Physiological Sciences 68 207-219. (https://doi.org/10.1007/s12576018-0597-5)

Hugle T, Geurts J, Nuesch C, Muller-Gerbl M \& Valderrabano V 2012 Aging and osteoarthritis: an inevitable encounter? Journal of Aging Research 2012 950192. (https://doi.org/10.1155/2012/950192)

Huskisson EC, Taylor RT, Burston D, Chuter PJ \& Hart FD 1970 Evening indomethacin in the treatment of rheumatoid arthritis. Annals of the Rheumatic Diseases 29 393-396. (https://doi.org/10.1136/ard.29.4.393)

Husse J, Eichele G \& Oster H 2015 Synchronization of the mammalian circadian timing system: light can control peripheral clocks independently of the SCN clock: alternate routes of entrainment optimize the alignment of the body's circadian clock network with external time. BioEssays 37 1119-1128. (https://doi.org/10.1002/ bies.201500026)

Igarashi K, Saeki S \& Shinoda H 2013 Diurnal rhythms in the incorporation and secretion of $3 \mathrm{H}$-proline and $3 \mathrm{H}$-galactose by cartilage cells and osteoblasts in various bone-forming sites in growing rats. Orthodontic Waves 72 11-15. (https://doi.org/10.1016/j. odw.2012.09.001)

Iwamoto M, Ohta Y, Larmour C \& Enomoto-Iwamoto M 2013 Towards regeneration of articular cartilage. Birth Defects Research Part C 99 192-202. (https://doi.org/10.1002/bdrc.21042)

Izumo M, Pejchal M, Schook AC, Lange RP, Walisser JA, Sato TR, Wang X, Bradfield CA \& Takahashi JS 2014 Differential effects of light and feeding on circadian organization of peripheral clocks in a forebrain Bmal1 mutant. eLife 3 e04617. (https://doi.org/10.7554/ eLife.04617)

James AW, Shen J, Khadarian K, Pang S, Chung G, Goyal R, Asatrian G Velasco O, Kim J, Zhang X, et al. 2014 Lentiviral delivery of PPAR $\gamma$ shRNA alters the balance of osteogenesis and adipogenesis, improving bone microarchitecture. Tissue Engineering: Part A 20 2699-2710. (https://doi.org/10.1089/ten.tea.2013.0736)

Jubiz W, Canterbury JM, Reiss E \& Tyler FH 1972 Circadian rhythm in serum parathyroid hormone concentration in human subjects: correlation with serum calcium, phosphate, albumin, and growth hormone levels. Journal of Clinical Investigation 51 2040-2046. (https://doi.org/10.1172/JCI107010)

Jud C \& Albrecht U 2006 Circadian rhythms in murine pups develop in absence of a functional maternal circadian clock. Journal of Biological Rhythms 21 149-154. (https://doi.org/10.1177/0748730406286264)

Kanbe K, Inoue K, Xiang C \& Chen Q 2006 Identification of clock as a mechanosensitive gene by large-scale DNA microarray analysis: downregulation in osteoarthritic cartilage. Modern Rheumatology 16 131-136. (https://doi.org/10.1007/s10165-006-0469-3)

Kawai M \& Rosen CJ 2010 PPAR $\gamma$ : a circadian transcription factor in adipogenesis and osteogenesis. Nature Reviews: Endocrinology 6 629-636. (https://doi.org/10.1038/nrendo.2010.155)

Kawai M, Green CB, Lecka-Czernik B, Douris N, Gilbert MR, Kojima S, Ackert-Bicknell C, Garg N, Horowitz MC, Adamo ML, et al. 2010a A circadian-regulated gene, Nocturnin, promotes adipogenesis by stimulating PPAR- $\gamma$ nuclear translocation. PNAS 107 10508-10513. (https://doi.org/10.1073/pnas.1000788107)

Kawai M, Delany AM, Green CB, Adamo ML \& Rosen CJ $2010 b$ Nocturnin suppresses Igf1 expression in bone by targeting the $3^{\prime}$ untranslated region of Igf1 mRNA. Endocrinology 151 4861-4870. (https://doi. org/10.1210/en.2010-0407)

Kawai M, Kinoshita S, Shimba S, Ozono K \& Michigami T 2014 Sympathetic activation induces skeletal FGF23 expression in a circadian rhythm-dependent manner. Journal of Biological Chemistry 289 1457-1466. (https://doi.org/10.1074/jbc.M113.500850)

Kc R, Li X, Forsyth CB, Voigt RM, Summa KC, Vitaterna MH, Tryniszewska B, Keshavarzian A, Turek FW, Meng QJ, et al. 2015 Osteoarthritis-like pathologic changes in the knee joint induced by environmental disruption of circadian rhythms is potentiated by a high-fat diet. Scientific Reports 5 16896. (https://doi.org/10.1038/ srep16896)

Kember NF \& Walker KVR 1971 Control of bone growth in rats. Nature 229 428-429. (https://doi.org/10.1038/229428a0)

Khurana S, Bokkers A, Geijs DJ, Schivo S, Karperien M \& Post JN 2019 In silico validation of a cartilage specific circadian clock: mutation of BMAL1 increased MMP expression. Osteoarthritis and Cartilage 27 S193-S194. (https://doi.org/10.1016/j.joca.2019.02.297)

Kim HA \& Blanco FJ 2007 Cell death and apoptosis in osteoarthritic cartilage. Current Drug Targets $8333-345$. (https://doi. org/10.2174/138945007779940025)

Kim JH \& Kim N 2014 Regulation of NFATc1 in osteoclast differentiation. Journal of Bone Metabolism 21 233-241. (https://doi.org/10.11005/ jbm.2014.21.4.233

King DP, Zhao Y, Sangoram AM, Wilsbacher LD, Tanaka M, Antoch MP, Steeves TD, Vitaterna MH, Kornhauser JM, Lowrey PL, et al. 1997 Positional cloning of the mouse circadian clock gene. Cell 89 641-653. (https://doi.org/10.1016/s0092-8674(00)80245-7) https://joe.bioscientifica.com

https://doi.org/10.1530/JOE-19-0256 (c) 2019 Society for Endocrinology Published by Bioscientifica Ltd. Printed in Great Britain 
Knäuper V, Bailey L, Worley JR, Soloway P, Patterson ML \& Murphy G 2002 Cellular activation of proMMP-13 by MT1-MMP depends on the C-terminal domain of MMP-13. FEBS Letters 532 127-130. (https:// doi.org/10.1016/s0014-5793(02)03654-2)

Komoto S, Kondo H, Fukuta O \& Togari A 2012 Comparison of $\beta$-adrenergic and glucocorticoid signaling on clock gene and osteoblast-related gene expressions in human osteoblast. Chronobiology International 29 66-74. (https://doi.org/10.3109/07420 528.2011.636496)

Kondratov RV, Kondratova AA, Gorbacheva VY, Vykhovanets OV \& Antoch MP 2006 Early aging and age-related pathologies in mice deficient in BMAL1, the core component of the circadian clock. Genes and Development 20 1868-1873. (https://doi.org/10.1101/ gad.1432206)

Kong SY, Stabler TV, Criscione LG, Elliott AL, Jordan JM \& Kraus VB 2006 Diurnal variation of serum and urine biomarkers in patients with radiographic knee osteoarthritis. Arthritis and Rheumatism $\mathbf{5 4}$ 2496-2504. (https://doi.org/10.1002/art.21977)

Kowalska E \& Brown SA 2007 Peripheral clocks: keeping up with the master clock. Cold Spring Harbor Symposia on Quantitative Biology 72 301-305. (https://doi.org/10.1101/sqb.2007.72.014)

Kowanko IC, Pownall R, Knapp MS, Swannell AJ \& Mahoney PG 1981 Circadian variations in the signs and symptoms of rheumatoid arthritis and in the therapeutic effectiveness of flurbiprofen at different times of day. British Journal of Clinical Pharmacology 11 477-484. (https://doi.org/10.1111/j.1365-2125.1981.tb01153.x)

Kramer A, Yang FC, Snodgrass P, Li X, Scammell TE, Davis FC \& Weitz CJ 2001 Regulation of daily locomotor activity and sleep by hypothalamic EGF receptor signaling. Science 294 2511-2515. (https://doi.org/10.1126/science.1067716)

Kume K, Zylka MJ, Sriram S, Shearman LP, Weaver DR, Jin X, Maywood ES, Hastings MH \& Reppert SM 1999 mCRY1 and mCRY2 are essential components of the negative limb of the circadian clock feedback loop. Cell 98 193-205. (https://doi.org/10.1016/s00928674(00)81014-4)

Lee C, Etchegaray JP, Cagampang FR, Loudon AS \& Reppert SM 2001 Posttranslational mechanisms regulate the mammalian circadian clock. Cell 107 855-867. (https://doi.org/10.1016/s00928674(01)00610-9)

Levi F, Le Louarn C \& Reinberg A 1985 Timing optimizes sustained-release indomethacin treatment of osteoarthritis. Clinical Pharmacology and Therapeutics 37 77-84. (https://doi.org/10.1038/clpt.1985.15)

Li R, Yue J, Zhang Y, Zhou L, Hao W, Yuan J, Qiang B, Ding JM, Peng X \& Cao JM 2008 CLOCK/BMAL1 regulates human nocturnin transcription through binding to the E-box of nocturnin promoter. Molecular and Cellular Biochemistry 317 169-177. (https://doi. org/10.1007/s11010-008-9846-x)

Li C, Chai Y, Wang L, Gao B, Chen H, Gao P, Zhou FQ, Luo X, Crane JL, Yu B, et al. 2017 Programmed cell senescence in skeleton during late puberty. Nature Communications 8 1312. (https://doi.org/10.1038/ s41467-017-01509-0)

Li X, Liu N, Gu B, Hu W, Li Y, Guo B \& Zhang D 2018 BMAL1 regulates balance of osteogenic-osteoclastic function of bone marrow mesenchymal stem cells in type 2 diabetes mellitus through the NF-кB pathway. Molecular Biology Reports 45 1691-1704. (https://doi. org/10.1007/s11033-018-4312-7)

Longo VD \& Panda S 2016 Fasting, circadian rhythms, and time restricted feeding in healthy lifespan. Cell Metabolism 23 1048-1059. (https:// doi.org/10.1016/i.cmet.2016.06.001)

Lowrey PL \& Takahashi JS 2011 Genetics of circadian rhythms in mammalian model organisms. Advances in Genetics $\mathbf{7 4} 175-230$. (https://doi.org/10.1016/B978-0-12-387690-4.00006-4)

Luchavova M, Zikan V, Michalska D, Raska I, Kubena AA \& Stepan JJ 2011 The effect of timing of teriparatide treatment on the circadian rhythm of bone turnover in postmenopausal osteoporosis. European Journal of Endocrinology 164 643-648. (https://doi.org/10.1530/EJE-10-1108)
Lui JC, Garrison P, Nguyen Q, Ad M, Keembiyehetty C, Chen W, Jee YH, Landman E, Nilsson O, Barnes KM, et al. 2016 EZH1 and EZH2 promote skeletal growth by repressing inhibitors of chondrocyte proliferation and hypertrophy. Nature Communications 713685. (https://doi.org/10.1038/ncomms13685)

Maronde E, Schilling AF, Seitz S, Schinke T, Schmutz I, Horst G van der, Amling M \& Albrecht U 2010 The clock genes Period 2 and Cryptochrome 2 differentially balance bone formation. PLOS ONE $\mathbf{5}$ e11527. (https://doi.org/10.1371/journal.pone.0011527)

Mescher AL 20167 Cartilage. In Junqueira's Basic Histology: Text and Atlas, 14th ed., pp 129-137. New York, NY, USA: McGraw-Hill Education.

Miedlich SU, Zalutskaya A, Zhu ED \& Demay MB 2010 Phosphateinduced apoptosis of hypertrophic chondrocytes is associated with a decrease in mitochondrial membrane potential and is dependent upon ERK1/2 phosphorylation. Journal of Biological Chemistry 285 18270-18275. (https://doi.org/10.1074/jbc.M109.098616)

Mitsui S, Yamaguchi S, Matsuo T, Ishida Y \& Okamura H 2001 Antagonistic role of E4BP4 and PAR proteins in the circadian oscillatory mechanism. Genes and Development 15 995-1006. (https:// doi.org/10.1101/gad.873501)

Mohawk JA, Green CB \& Takahashi JS 2012 Central and peripheral circadian clocks in mammals. Annual Review of Neuroscience $\mathbf{3 5}$ 445-462. (https://doi.org/10.1146/annurev-neuro-060909-153128)

Moore RY \& Eichler VB 1972 Loss of a circadian adrenal corticosterone rhythm following suprachiasmatic lesions in the rat. Brain Research 42 201-206. (https://doi.org/10.1016/0006-8993(72)90054-6)

Moore RY \& Klein DC 1974 Visual pathways and the central neural control of a circadian rhythm in pineal serotonin N-acetyltransferase activity. Brain Research 71 17-33. (https://doi.org/10.1016/00068993(74)90188-7)

Moreira LD, Oliveira ML, Lirani-Galvão AP, Marin-Mio RV, Santos RN \& Lazaretti-Castro M 2014 Physical exercise and osteoporosis: effects of different types of exercises on bone and physical function of postmenopausal women. Arquivos Brasileiros de Endocrinologia e Metabologia 58 514-522. (https://doi.org/10.1590/00042730000003374)

Morgan EF, Barnes GL \& Einhorn TA 2013 The bone organ system. In Osteoporosis, pp 3-20. Amsterdam, Netherlands: Elsevier. (https://doi. org/10.1016/B978-0-12-415853-5.00001-7)

Naito S, Shiomi T, Okada A, Kimura T, Chijiiwa M, Fujita Y, Yatabe T, Komiya K, Enomoto H, Fujikawa K, et al. 2007 Expression of ADAMTS4 (aggrecanase-1) in human osteoarthritic cartilage. Pathology International 57 703-711. (https://doi.org/10.1111/j.14401827.2007.02167.x)

Ng HY, Lee K-XA \& Shen Y-F 2017 Articular cartilage: structure, composition, injuries and repair. JSM Bone and Joint Diseases 61010.

Noguchi T, Hussein AI, Horowitz N, Carroll D, Gower AC, Demissie S \& Gerstenfeld LC 2018 Hypophosphatemia regulates molecular mechanisms of circadian rhythm. Scientific Reports 8 13756. (https:// doi.org/10.1038/s41598-018-31830-7)

Okubo N, Minami Y, Fujiwara H, Umemura Y, Tsuchiya Y, Shirai T, Oda R, Inokawa H, Kubo T \& Yagita K 2013 Prolonged bioluminescence monitoring in mouse ex vivo bone culture revealed persistent circadian rhythms in articular cartilages and growth plates. PLOS ONE 8 e78306. (https://doi.org/10.1371/journal.pone.0078306)

Okubo N, Fujiwara H, Minami Y, Kunimoto T, Hosokawa T, Umemura Y, Inokawa $\mathrm{H}$, Asada M, Oda R, Kubo T, et al. 2015 Parathyroid hormone resets the cartilage circadian clock of the organ-cultured murine femur. Acta Orthopaedica 86 627-631. (https://doi.org/10.3109/17453 674.2015.1029393)

Pan G, Cao J, Yang N, Ding K, Fan C, Xiong WC, Hamrick M, Isales CM \& Shi XM 2014 Role of glucocorticoid-induced leucine zipper (GILZ) in bone acquisition. Journal of Biological Chemistry 289 19373-19382. (https://doi.org/10.1074/jbc.M113.535237)

Panda S, Sato TK, Castrucci AM, Rollag MD, DeGrip WJ, Hogenesch JB, Provencio I \& Kay SA 2002a Melanopsin (Opn4) requirement for https://joe.bioscientifica.com

https://doi.org/10.1530/JOE-19-0256
(C) 2019 Society for Endocrinology Published by Bioscientifica Ltd. Printed in Great Britain 
normal light-induced circadian phase shifting. Science 2982213 2216. (https://doi.org/10.1126/science.1076848)

Panda S, Antoch MP, Miller BH, Su AI, Schook AB, Straume M, Schultz PG, Kay SA, Takahashi JS \& Hogenesch JB 2002b Coordinated transcription of key pathways in the mouse by the circadian clock. Cell 109 307-320. (https://doi.org/10.1016/s0092-8674(02)00722-5)

Pittendrigh CS 1993 Temporal organization: reflections of a Darwinian clock-watcher. Annual Review of Physiology 55 16-54. (https://doi. org/10.1146/annurev.ph.55.030193.000313)

Preitner N, Damiola F, Lopez-Molina L, Zakany J, Duboule D, Albrecht U \& Schibler U 2002 The orphan nuclear receptor REV-ERB $\alpha$ controls circadian transcription within the positive limb of the mammalian circadian oscillator. Cell 110 251-260. (https://doi.org/10.1016/s00928674(02)00825-5)

Preußner M \& Heyd F 2016 Post-transcriptional control of the mammalian circadian clock: implications for health and disease. Pflugers Archiv 468 983-991. (https://doi.org/10.1007/s00424-016-1820-y)

Qiu T, Crane JL, Xie L, Xian L, Xie H \& Cao X 2018 IGF-I induced phosphorylation of PTH receptor enhances osteoblast to osteocyte transition. Bone Research 6 5. (https://doi.org/10.1038/s41413-0170002-7)

Quevedo I \& Zuniga AM 2010 Low bone mineral density in rotating-shift workers. Journal of Clinical Densitometry 13 467-469. (https://doi. org/10.1016/j.jocd.2010.07.004)

Ranger AM, Gerstenfeld LC, Wang J, Kon T, Bae H, Gravallese EM, Glimcher MJ \& Glimcher LH 2000 The nuclear factor of activated $\mathrm{T}$ cells (Nfat) transcription factor Nfatp (Nfatc2) is a repressor of chondrogenesis. Journal of Experimental Medicine 191 9-22. (https:// doi.org/10.1084/jem.191.1.9)

Raugstad TS, Mølster A, Haukeland W, Hestenes O \& Olerud S 1979 Treatment of pertrochanteric and subtrochanteric fractures of the femur by the Ender method. Clinical Orthopaedics and Related Research 138 231-237.

Reppert SM \& Schwartz WJ 1986 Maternal suprachiasmatic nuclei are necessary for maternal coordination of the developing circadian system. Journal of Neuroscience 6 2724-2729. (https://doi.org/10.1523/ JNEUROSCI.06-09-02724.1986)

Reppert SM \& Weaver DR 2002 Coordination of circadian timing in mammals. Nature 418 935-941. (https://doi.org/10.1038/ nature00965)

Riley LA \& Esser KA 2017 The role of the molecular clock in skeleta muscle and what it is teaching us about muscle-bone crosstalk. Current Osteoporosis Reports 15 222-230. (https://doi.org/10.1007/ s11914-017-0363-2)

Roach HI, Yamada N, Cheung KSC, Tilley S, Clarke NMP, Oreffo ROC, Kokubun S \& Bronner F 2005 Association between the abnormal expression of matrix-degrading enzymes by human osteoarthritic chondrocytes and demethylation of specific CpG sites in the promoter regions. Arthritis and Rheumatism 52 3110-3124. (https:// doi.org/10.1002/art.21300)

Roddy E, Zhang W \& Doherty M 2005 Aerobic walking or strengthening exercise for osteoarthritis of the knee? A systematic review. Annals of the Rheumatic Diseases 64 544-548. (https://doi.org/10.1136/ ard.2004.028746)

Russell JE, Grazman B \& Simmons DJ 1984 Mineralization in rat metaphyseal bone exhibits a circadian stage dependency. Proceedings of the Society for Experimental Biology and Medicine 176 342-345. (https://doi.org/10.3181/00379727-176-41880)

Russell JE, Simmons DJ, Huber B \& Roos BA 1983 Meal timing as a Zeitgeber for skeletal deoxyribonucleic acid and collagen synthesis rhythms. Endocrinology 113 2035-2042. (https://doi.org/10.1210/ endo-113-6-2035)

Sabbagh Y, Carpenter TO \& Demay MB 2005 Hypophosphatemia leads to rickets by impairing caspase-mediated apoptosis of hypertrophic chondrocytes. PNAS 102 9637-9642. (https://doi.org/10.1073/ pnas.0502249102)
Samsa WE, Vasanji A, Midura RJ \& Kondratov RV 2016 Deficiency of circadian clock protein BMAL1 in mice results in a low bone mass phenotype. Bone 84 194-203. (https://doi.org/10.1016/j. bone.2016.01.006)

Sato TK, Panda S, Miraglia LJ, Reyes TM, Rudic RD, McNamara P, Naik KA, FitzGerald GA, Kay SA \& Hogenesch JB 2004 A functional genomics strategy reveals Rora as a component of the mammalian circadian clock. Neuron 43 527-537. (https://doi.org/10.1016/j. neuron.2004.07.018)

Scharstuhl A, van Beuningen HM, Vitters EL, van der Kraan PM \& van den Berg WB 2002 Loss of transforming growth factor counteraction on interleukin 1 mediated effects in cartilage of old mice. Annals of the Rheumatic Diseases 61 1095-1098. (https://doi.org/10.1136/ ard.61.12.1095)

Scheer FA, Pirovano C, Van Someren EJ \& Buijs RM 2005 Environmental light and suprachiasmatic nucleus interact in the regulation of body temperature. Neuroscience 132 465-477. (https://doi.org/10.1016/j. neuroscience.2004.12.012)

Schroeder AM \& Colwell CS 2013 How to fix a broken clock. Trends in Pharmacological Sciences 34 605-619. (https://doi.org/10.1016/j. tips.2013.09.002)

Scott FL, Denault JB, Riedl SJ, Shin H, Renatus M \& Salvesen GS 2005 XIAP inhibits caspase- 3 and -7 using two binding sites: evolutionarily conserved mechanism of IAPs. EMBO Journal 24 645-655. (https:// doi.org/10.1038/sj.emboj.7600544)

Selfridge JM, Gotoh T, Schiffhauer S, Liu J, Stauffer PE, Li A, Capelluto DGS \& Finkielstein CV 2016 Chronotherapy: intuitive, sound, founded... but not broadly applied. Drugs 76 1507-1521. (https://doi.org/10.1007/s40265-016-0646-4)

Shao P, Ohtsuka-Isoya M \& Shinoda H 2003 Circadian rhythms in serum bone markers and their relation to the effect of etidronate in rats. Chronobiology International 20 325-336. (https://doi.org/10.1081/CBI120019343)

Shearman LP, Sriram S, Weaver DR, Maywood ES, Chaves I, Zheng B, Kume K, Lee CC, van der Horst GT, Hastings MH, et al. 2000 Interacting molecular loops in the mammalian circadian clock. Science 288 1013-1019. (https://doi.org/10.1126/science.288.5468.1013)

Shi X, Shi W, Li Q, Song B, Wan M, Bai S \& Cao X 2003 A glucocorticoidinduced leucine-zipper protein, GILZ, inhibits adipogenesis of mesenchymal cells. EMBO Reports 4 374-380. (https://doi. org/10.1038/sj.embor.embor805)

Shockley KR, Lazarenko OP, Czernik PJ, Rosen CJ, Churchill GA \& LeckaCzernik B 2009 PPARgamma2 nuclear receptor controls multiple regulatory pathways of osteoblast differentiation from marrow mesenchymal stem cells. Journal of Cellular Biochemistry 106 232-246. (https://doi.org/10.1002/jcb.21994)

Simmons DJ 1962 Diurnal periodicity in epiphyseal growth cartilage. Nature 195 82-83. (https://doi.org/10.1038/195082a0)

Simmons DJ 1964a Circadian mitotic rhythm in epiphyseal cartilage. Nature 202 906-907. (https://doi.org/10.1038/202906a0)

Simmons DJ 1964b Periodicity of S35 uptake in rat femurs. Experientia 20 137-138. (https://doi.org/10.1007/bf02150697)

Simmons DJ \& Nichols G 1966 Diurnal periodicity in the metabolic activity of bone tissue. American Journal of Physiology 210 411-418. (https://doi.org/10.1152/ajplegacy.1966.210.2.411)

Simoni A, Wolfgang W, Topping MP, Kavlie RG, Stanewsky R \& Albert JT 2014 A mechanosensory pathway to the Drosophila circadian clock. Science 343 525-528. (https://doi.org/10.1126/ science.1245710)

Snelling SJB, Forster A, Mukherjee S, Price AJ \& Poulsen RC 2016 The chondrocyte-intrinsic circadian clock is disrupted in human osteoarthritis. Chronobiology International 33 574-579. (https://doi.org /10.3109/07420528.2016.1158183)

Solt LA, Kojetin DJ \& Burris TP 2011 The REV-ERBs and RORs: molecular links between circadian rhythms and lipid homeostasis. Future Medicinal Chemistry 3 623-638. (https://doi.org/10.4155/fmc.11.9) https://joe.bioscientifica.com

https://doi.org/10.1530/JOE-19-0256 (c) 2019 Society for Endocrinology Published by Bioscientifica Ltd. Printed in Great Britain 
Solt LA, Wang Y, Banerjee S, Hughes T, Kojetin DJ, Lundasen T, Shin Y, Liu J, Cameron MD, Noel R, et al. 2012 Regulation of circadian behavior and metabolism by synthetic REV-ERB agonists. Nature $\mathbf{4 8 5}$ 62-68. (https://doi.org/10.1038/nature11030)

Song RH, Tortorella MD, Malfait AM, Alston JT, Yang Z, Arner EC \& Griggs DW 2007 Aggrecan degradation in human articular cartilage explants is mediated by both ADAMTS-4 and ADAMTS-5. Arthritis and Rheumatism 56 575-585. (https://doi.org/10.1002/art.22334)

Soul J, Dunn SL, Anand S, Serracino-Inglott F, Schwartz JM, BootHandford RP \& Hardingham TE 2018 Stratification of knee osteoarthritis: two major patient subgroups identified by genome-wide expression analysis of articular cartilage. Annals of the Rheumatic Diseases 77 423-423. (https://doi.org/10.1136/ annrheumdis-2017-212603)

Srivastava AK, Bhattacharyya S, Li X, Mohan S \& Baylink DJ 2001 Circadian and longitudinal variation of serum C-telopeptide, osteocalcin, and skeletal alkaline phosphatase in $\mathrm{C} 3 \mathrm{H} / \mathrm{HeJ}$ mice. Bone 29 361-367. (https://doi.org/10.1016/S87563282(01)00581-6)

Stevenson S, Hunziker EB, Herrmann W \& Schenk RK 1990 Is longitudinal bone growth influenced by diurnal variation in the mitotic activity of chondrocytes of the growth plate? Journal of Orthopaedic Research 8 132-135. (https://doi.org/10.1002/ jor.1100080117)

Storch KF, Lipan O, Leykin I, Viswanathan N, Davis FC, Wong WH \& Weitz CJ 2002 Extensive and divergent circadian gene expression in liver and heart. Nature $\mathbf{4 1 7}$ 78-83. (https://doi.org/10.1038/ nature744)

Storch KF, Paz C, Signorovitch J, Raviola E, Pawlyk B, Li T \& Weitz CJ 2007 Intrinsic circadian clock of the mammalian retina: importance for retinal processing of visual information. Cell 130 730-741. (https://doi.org/10.1016/j.cell.2007.06.045)

Stubblefield JJ, Terrien J \& Green CB 2012 Nocturnin: at the crossroads of clocks and metabolism. Trends in Endocrinology and Metabolism 23 326-333. (https://doi.org/10.1016/j.tem.2012.03.007)

Swanson C, Shea SA, Wolfe P, Markwardt S, Cain SW, Munch M, Czeisler CA, Orwoll ES \& Buxton OM 2017 24-hour profile of serum sclerostin and its association with bone biomarkers in men. Osteoporosis International 28 3205-3213. (https://doi.org/10.1007/ s00198-017-4162-5)

Takarada T, Kodama A, Hotta S, Mieda M, Shimba S, Hinoi E \& Yoneda Y 2012 Clock genes influence gene expression in growth plate and endochondral ossification in mice. Journal of Biological Chemistry 287 36081-36095. (https://doi.org/10.1074/jbc.M112.408963)

Takarada T, Xu C, Ochi H, Nakazato R, Yamada D, Nakamura S, Kodama A, Shimba S, Mieda M, Fukasawa K, et al. 2017 Bone resorption is regulated by circadian clock in osteoblasts. Journal of Bone and Mineral Research 32 872-881. (https://doi.org/10.1002/ jbmr.3053)

Takeda S, Elefteriou F, Levasseur R, Liu X, Zhao L, Parker KL, Armstrong D, Ducy P \& Karsenty G 2002 Leptin regulates bone formation via the sympathetic nervous system. Cell 111 305-317. (https://doi.org/10.1016/s0092-8674(02)01049-8)

Ueda HR, Hayashi S, Chen W, Sano M, Machida M, Shigeyoshi Y, Iino M \& Hashimoto S 2005 System-level identification of transcriptional circuits underlying mammalian circadian clocks. Nature Genetics $\mathbf{3 7}$ 187-192. (https://doi.org/10.1038/ng1504)

Umemura Y, Koike N, Ohashi M, Tsuchiya Y, Meng QJ, Minami Y, Hara M, Hisatomi M \& Yagita K 2017 Involvement of posttranscriptional regulation of Clock in the emergence of circadian clock oscillation during mouse development. PNAS 114 E7479_ E7488. (https://doi.org/10.1073/pnas.1703170114)

Velasco-Loyden G, Arribas J \& López-Casillas F 2004 The shedding of betaglycan is regulated by pervanadate and mediated by membrane type matrix metalloprotease-1. Journal of Biological Chemistry 279 7721-7733. (https://doi.org/10.1074/jbc.M306499200)
Verma P \& Dalal K 2011 ADAMTS-4 and ADAMTS-5: key enzymes in osteoarthritis. Journal of Cellular Biochemistry 112 3507-3514. (https:// doi.org/10.1002/jcb.23298)

Vortkamp A, Lee K, Lanske B, Segre GV, Kronenberg HM \& Tabin CJ 1996 Regulation of rate of cartilage differentiation by Indian hedgehog and PTH-related protein. Science 273 613-622. (https://doi.org/10.1126/ science.273.5275.613)

Walker KV \& Kember NF 1972 Cell kinetics of growth cartilage in the rat tibia. I. Measurements in young male rats. Cell and Tissue Kinetics 5 401-408. (https://doi.org/10.1111/j.1365-2184.1972.tb00378.x)

Wallach T \& Kramer A 2015 Chemical chronobiology: toward drugs manipulating time. FEBS Letters 589 1530-1538. (https://doi. org/10.1016/j.febslet.2015.04.059)

Wang J, Gardner BM, Lu Q, Rodova M, Woodbury BG, Yost JG, Roby KF, Pinson DM, Tawfik O \& Anderson HC 2009 Transcription factor Nfat1 deficiency causes osteoarthritis through dysfunction of adult articular chondrocytes. Journal of Pathology 219 163-172. (https://doi. org/10.1002/path.2578)

Wang W, Rigueur D \& Lyons KM 2014 TGF $\beta$ signaling in cartilage development and maintenance. Birth Defects Research: Part C, Embryo Today: Reviews 102 37-51. (https://doi.org/10.1002/bdrc.21058)

Xian L, Wu X, Pang L, Lou M, Rosen CJ, Qiu T, Crane J, Frassica F, Zhang L, Rodriguez JP, et al. 2012 Matrix IGF-1 maintains bone mass by activation of mTOR in mesenchymal stem cells. Nature Medicine $\mathbf{1 8}$ 1095-1101. (https://doi.org/10.1038/nm.2793)

Xu C, Ochi H, Fukuda T, Sato S, Sunamura S, Takarada T, Hinoi E, Okawa A \& Takeda S 2016 Circadian clock regulates bone resorption in mice. Journal of Bone and Mineral Research 31 1344-1355. (https:// doi.org/10.1002/jbmr.2803)

Yagita K, Horie K, Koinuma S, Nakamura W, Yamanaka I, Urasaki A, Shigeyoshi Y, Kawakami K, Shimada S, Takeda J, et al. 2010 Development of the circadian oscillator during differentiation of mouse embryonic stem cells in vitro. PNAS 107 3846-3851. (https:// doi.org/10.1073/pnas.0913256107)

Yang N \& Meng QJ 2016 Circadian clocks in articular cartilage and bone: a compass in the sea of matrices. Journal of Biological Rhythms $\mathbf{3 1}$ 415-427. (https://doi.org/10.1177/0748730416662748)

Yang W, Kang X, Liu J, Li H, Ma Z, Jin X, Qian Z, Xie T, Qin N, Feng D, et al. $2016 a$ Clock gene Bmal1 modulates human cartilage gene expression by crosstalk with Sirt1. Endocrinology 157 3096-3107. (https://doi.org/10.1210/en.2015-2042)

Yang G, Chen L, Grant GR, Paschos G, Song WL, Musiek ES, Lee V, McLoughlin SC, Grosser T, Cotsarelis G, et al. 2016b Timing of expression of the core clock gene Bmal1 influences its effects on aging and survival. Science Translational Medicine 8 324ra16. (https://doi. org/10.1126/scitranslmed.aad3305)

Yang N, Williams J, Pekovic-Vaughan V, Wang P, Olabi S, McConnell J, Gossan N, Hughes A, Cheung J, Streuli CH, et al. 2017 Cellular mechano-environment regulates the mammary circadian clock. Nature Communications 8 14287. (https://doi.org/10.1038/ ncomms14287)

Yoo SH, Yamazaki S, Lowrey PL, Shimomura K, Ko CH, Buhr ED, Siepka SM, Hong HK, Oh WJ, Yoo OJ, et al. 2004 PERIOD2::luciferase real-time reporting of circadian dynamics reveals persistent circadian oscillations in mouse peripheral tissues. PNAS 101 5339-5346. (https://doi.org/10.1073/pnas.0308709101)

Yuan G, Xu L, Cai T, Hua B, Sun N, Yan Z, Lu C \& Qian R 2019 Clock mutant promotes osteoarthritis by inhibiting the acetylation of NFkB. Osteoarthritis and Cartilage 27 922-931. (https://doi.org/10.1016/j. joca.2019.01.012)

Zhang W, Yang N \& Shi XM 2008 Regulation of mesenchymal stem cell osteogenic differentiation by glucocorticoid-induced leucine zipper (GILZ). Journal of Biological Chemistry 283 4723-4729. (https://doi. org/10.1074/jbc.M704147200)

Zhang R, Lahens NF, Ballance HI, Hughes ME \& Hogenesch JB 2014 A circadian gene expression atlas in mammals: implications for biology https://joe.bioscientifica.com

https://doi.org/10.1530/JOE-19-0256
(C) 2019 Society for Endocrinology Published by Bioscientifica Ltd. Printed in Great Britain 
and medicine. PNAS 111 16219-16224. (https://doi.org/10.1073/ pnas.1408886111)

Zhang Y, Fang B, Emmett MJ, Damle M, Sun Z, Feng D, Armour SM, Remsberg JR, Jager J, Soccio RE, et al. 2015 GENE REGULATION: Discrete functions of nuclear receptor Rev-erb $\alpha$ couple metabolism to the clock. Science 348 1488-1492. (https://doi.org/10.1126/science.aab3021)

Zvonic S, Ptitsyn AA, Conrad SA, Scott LK, Floyd ZE, Kilroy G, Wu X, Goh BC, Mynatt RL \& Gimble JM 2006 Characterization of peripheral circadian clocks in adipose tissues. Diabetes $\mathbf{5 5}$ 962-970. (https://doi.org/10.2337/diabetes.55.04.06. db05-0873)

Zvonic S, Ptitsyn AA, Kilroy G, Wu X, Conrad SA, Scott LK, Guilak F, Pelled G, Gazit D \& Gimble JM 2007 Circadian oscillation of gene expression in murine calvarial bone. Journal of Bone and Mineral Research 22 357-365. (https://doi.org/10.1359/ jbmr.061114)

Received in final form 9 August 2019

Accepted 29 August 2019

Accepted Preprint published online 29 August 2019 (c) 2019 Society for Endocrinology Published by Bioscientifica Ltd. 